John Thobo-Carlsen

\title{
Om litteratur på tærsklen til en verden uden litteratur
}

En sammenholdning af Barthes' og Benjamins syn på forholdet mellem sprog og litteratur

Når Roland Barthes (1915-1980) på den ene side hævder, at nydelsen og ubehaget for den enkelte ved at læse og skrive litteratur er knyttet til den udfordring og det besvær, som kroppen har med at forlige sig med sprogets generalitet, og Walter Benjamin (1892 -1940) på den anden side mener, at ens krop og andres kun er erkendbare i benævnelsen - vel at mærke i den udstrækning kroppen lader sig meddele, eller sagt på en anden måde, at det ved mennesker og ting, der lader sig meddele, er det sproglige - så synes det klart, at der for dem begge ikke har været nogen vej uden om sproget.

Barthes siger også, at »litteraturen ligner Racines heltinde Eriphile i tragedien Iphigénie, som dør af at vide, hvem hun er, men som lever ved at søge sig selv «, ${ }^{1}$ og ved andre lejligheder nævner han Orfeus-myten direkte som allegori på det litterære fænomen og det at skrive og læse:

»Denne mallarméske sprogbrug er Orfeus, som kun kan redde det, han elsker ved at give afkald på det, men som alligevel vender sig lidt om; det er litteraturen på tarsklen til Det forjattede Land, eller tærsklen til en verden uden litteratur som det alligevel er forfatternes opgave at vidne om. $\ll^{2}$

Paradokset i dette afspejler ikke alene Barthes' opfattelse af, hvilken type problemer litteraturen typisk håndterer, og i hvilken form det sker, men det er samtidig et billede på litteraturen som erkendelsesmodus og sandhedsgestalt.

Det er omkring indsigter af denne art, at Barthes og Benjamin synes at mødes i sproget og i litteraturen.

I Benjamins disputats, Der Begriff der Kunstkritik in der deutschen Romantik (1919), diskuteres filosoffen Fichtes tanker om begrebet refleksion i forhold til videnskab og kunst som en del af det erkendelsesmæssige grundlag for romantikken og, i det ærinde som Benjamin i denne afhandling er ude i, som 
grundlag for Novalis' og Friedrich Schlegels tanker om forholdet mellem kunst og den givne omverden. Benjamin resumerer, at Fichte ved refleksion forstår en umiddelbar og sikker erkendelsesform, der er karakteriseret ved en særlig intim sammenhæng mellem to bevidsthedsformer, nemlig viden som sådan på den ene side og bevidstheden om denne viden på den anden. Altså en bevidsthedsform som består i, at én bevidsthedsform bliver til indhold for en ny bevidsthedsform. ${ }^{3}$ Subjektet for denne handling er et jeg's uophørlige og umiddelbare bestræbelse på gennem refleksionens pseudoobjektive og -rationelle univers, at ankomme til en virkelighed (hos Fichte et »ikke-jeg «), som subjektet notorisk er en del af og $-\mathrm{i}$ og med den selvsamme refleksion - samtidig er forskellig fra. En autentisk kunst og digtning (og for den sags skyld videnskab) kan selvfølgelig ikke andet end dreje sig om dette, enten direkte eller på mere eller mindre allegorisk vis. Man kunne vanskeligt kalde det andet end virkelighedsflugt, hvis den ikke gjorde det. Fichte skriver således i sin etik, at kunsten »vender en transcendental synsvinkel til en almen. ... Ud fra et transcendentalt synspunkt er verden skabt, ud fra et alment synspunkt er den givet; ud fra et æstetisk synspunkt er den givet, men hele tiden med det aspekt at vise, hvordan den er skabt «. ${ }^{4}$

\section{Sprog, litteratur og moral}

Med litteraturen (og videnskaben) forsøger vi på tragisk, ja og for litteraturens vedkommende næsten 'hysterisk' vis at omgå den til tider ubekvemme kendsgerning, at vi er bundet til sproget, når vi skal forstå verden. Omgåelsen får karakter af et gigantisk mimetisk rollespil. På den ene side har vi en indsigt i sprogets fundamentale status og uomgængelige rolle for menneskets selvforståelse og omverdensopfattelse og forholdet mellem dem. Eller som Benjamin siger: »Der findes ingen hændelse eller ting hverken i den døde eller den levende natur, som ikke på en vis måde har del i sproget «.5

På den anden side har vi en temmelig lang erfaring med, at sproget faktisk lader sig bruge til hvad som helst, og altså også som led i vores (næsten) håbløse kamp for at kunne få lov til noget så tilsyneladende enkelt som at leve og erkende på én gang. Vi har nemlig opdaget, at sproget har flere funktioner eller roller, som vi kan spille på og spille ud mod hinanden: ${ }^{6}$ Den første kan vi kalde den pragmatiske. Den spiller vi på, når vi vil stille os til rådighed for den praktiske virkelighedsforståelse, som også er den dominerende. Når vi vil parre os med den gængse sprogbrug $\mathrm{i}$ en bestræbelse på gennem analogi og 'efterligning' at nå den virkelighed, som vi vitterligt attrår. Den anden kan vi så kalde den utopiske, selv om den altid er konkret sproglig, også hos Benjamin. 
Den har nemlig både indset tomgangen i det første projekt, og profeterer selv - $\mathrm{i}$ en art dekonstruktionsproces af allegoristisk konkret karakter, fordi den både må leve med den første funktion og ombryde den - forestillingen om en frihed i umiddelbar og uformidlet forståelse af menneskets liv i og med virkeligheden. Så faktisk kunne man godt, i hvert fald for Barthes' vedkommende, kalde den anden for den mest realistiske og den første for den mest idealistiske. Men uanset hvad man kalder dem, har begge sprogroller samme mål: ankomsten til virkeligheden.

Den første rolle fungerer med sproget som redskab, den 'direkte' vej igennem sproget. Den er egentlig illusionistisk, i den udstrækning den stiller sig tilfreds med 'sædvanlig praksis' og så at sige opløser sig selv som tegn eller 'bare' beslutter eller bliver 'enig' om (konsensus), at nu er vi ankommet! Den anden rolle må forblive i sproget, i tegnenes tale, da den må leve med konsekvenserne af den førstes ubekymrethed. Den må gå den omvej, der kræves for at afsnøre eller neutralisere, så godt det nu lader sig gøre, de betydninger, den første har institutionaliseret. Vi møder selvfølgelig begge sprogets roller i litteraturen. Den anden rolle er knyttet til tekstualiteten og konkretiseres som modus i en mere eller mindre intens udgave af dens semiotiske symbiose med den første. Den første rolle knyttes til teksten som semiotisk konkretion og finder typisk sin form i verket. Om mulighederne for at komme frem ad denne anden vej på de givne vilkår, siger Barthes:

»I sproget bliver underdanighed og magt altså uvægerligt sammenblandet. Hvis det, man kalder frihed, ikke bare er evnen til at unddrage sig magten, men også og især evnen til ikke at underkaste nogen, kan der altså kun findes frihed uden for sproget. Ulykkeligvis er det menneskelige sprog uden noget udenfor: det er en lukket dør. ... der [er] ikke andet at gøre end, om jeg så må sige, at snyde med sproget og tage sproget ved næsen. $\ll^{7}$

Litteratur kan være måden at gøre det på. Efter Barthes’ påpegning af det underkastende og det tvingende i sprogets om ikke voldsudøvelse så magtudfoldelse, hvilket hans syn på litterær sprogbrug bl.a. må ses på baggrund af, er det karakteristisk, at Benjamin når frem til, at sproget må være samfundets uvoldelige sfære par exellence. Beviset skulle her være, at løgnen er straffri:

»Er det overhovedet muligt at bilægge konflikter uvoldeligt? ... Det mest dybtgående eksempel er måske samtalen betragtet som en teknik for civil overenskomst. Her er uvoldelig enighed nemlig ikke blot mulig; at volden principielt er udelukket, kan bevises ved et vigtigt forhold: ved 
at løgn er straffri. ... Det beviser, at der i overenskomsten mellem mennesker findes en sfære, der er så uvoldelig, at den er fuldstændig utilgængelig for vold: den egentlige 'forståelses' sfære, sproget. $\ll^{8}$

Hvis Barthes' syn på forholdet mellem magtudøvelse i og med sproget og den litterære sprogbrugs mulighed for at omgå denne har rødder i eksistentialismens transcenderende varen, får vi med dette eksempel bekræftet, at Benjamins sprogsyn, som vil blive præsenteret i næste afsnit, er apriorisk reducerbart til meddelbarhed. Da sproget altid, uanset hvilken udgave det fremtræder i, meddeler sig selv, bliver vold og magt i sproget opløst i særlige mytiske udgaver af meddelbarhed, som, hvis de skal udfordres i sandhedens tjeneste, må modstilles billeder, der viser hulheden i myten og samtidig åbenbarer bestræbelsen mod en sandhed, der ikke alene transcenderer væren, men også transcenderer den endelige verden.

På denne lidt omvendte måde bliver Barthes' og Benjamins forhold til litteraturen efterhånden også til et spørgsmål om moralitet, dvs. hvorvidt litteraturen og videnskaben om litteratur undslår sig selv-fremstillingen (i anti-subjektivt perspektiv). »Moralitet skal her forstås som det stik modsatte af moralen (det er tanken om kroppen i sproglig forstand) «. ${ }^{9}$ Mere eksplicit: om litteraturen i sproget og skriften lever op til sin forpligtelse at gestalte den krop eller rettere forbinde den krop og det følelsesliv (Benjamin ville sige ånd), som den 'moderne' civilisation har udskilt eller adskilt. Benjamin ville, som vi skal se, betragte denne splittelse i syndefaldets perspektiv og betegne den som en ren metafysisk konstruktion, som har sit udspring i en empirisk bevidsthed og sit erkendelsesgrundlag $i$ et naturvidenskabeligt verdensbillede. Litteraturen ville være det konkrete og historiske sted, der gennem dens særlige sproglige gestaltningsevne (allegorier o.lign.) kan formidle håbet om heling af det splittede, om det forskelsløse, om det paradisiske. Barthes har afskrevet troen i religiøs forstand, i stedet sætter han ritualet i bred forstand. ${ }^{10}$ Hans højeste nydelse bliver så dennesidig, at den ikke kommer ud over sproget, dvs. talen og skriven, til gengæld får det næsten fysisk karakter. ${ }^{11}$ Der ligger i $\emptyset$ vrigt hans moralske begribelse af hele tekstualitetskomplekset, skribentrolle-tekst-læserrolle i ét.

\section{Sprog og erkendelse}

For Benjamin og Barthes synes litteraturen som sagt uadskillelig fra det sprog, den taler i. På den ene side er den det så meget, at dens værdi for dem, der benytter sig af den (formuleringen er bevidst neutral), ligger i den særlige egen- 
skab ved sproget, der gør, at det er i stand til at indrette sig mod sig selv, af Roman Jakobson som bekendt kaldt sprogets poetiske funktion. ${ }^{12}$ På den anden side ville værdien hurtigt svækkes, hvis denne egenskab ved sproget ikke samtidig havde den funktion på en underfundig måde at gøre brugerne af den bedre i stand til at forstå, acceptere og udfordre den virkelighed, de lever i. Men for bedre at kunne forstå, hvorfor det forholder sig sådan, må vi blive en stund ved Benjamins og Barthes' mere principielle holdninger til fænomenet sprog for siden at vende tilbage til litteraturen. ${ }^{13}$

Walter Benjamins erkendelsesperspektiv er transcendentalt absolutistisk, mens vejen er konkret sproglig. Barthes kæmper sig fri af en erkendelse funderet på en ren empirisk objektivitet, idet han udfordrer dennes mytiske forestilling om Sandhed gennem fremstillingens tilnærmelseskarakter ud fra det sproglige subjekts perspektiv. Set fra Benjamins side er menneskets 'sprogevne' tæt forbundet med syndefaldet, som jeg antydede før: »syndefaldet er det menneskelige ords fødselsstund $\ll{ }^{14}$

Meget summarisk forholder det sig sådan, idet Benjamin følger skabelsesberetningen, at »I begyndelsen var ordet, og ordet var hos Gud « ${ }^{15}$ og Gud skabte tingene i naturen og menneskene i og med sproget. Men tingene og menneskene blev ikke skabt på den samme måde, der var en afgørende forskel. Tingene i naturen blev skabt i sproget ved navnet. Og ved navnet blev tingen erkendbar. Men »navnets absolutte forhold til erkendelsen består alene hos Gud, kun der er navnet, fordi det i sit inderste er identisk med det skabende ord, erkendelsens rene medium $\ll .{ }^{16}$ Således som Gud benævner tingene, efter at de har fået navn og derved erkender dem - »Og Gud så at det var godt «, som Benjamin citerer -, således også mennesket. Derfor blev mennesket ikke skabt $a f$ ordet, mennesket blev ikke benævnt, Gud ville ikke underlægge mennesket sproget, men i stedet give det et sprog selv. Mennesket blev skabt i Guds billede (den skabendes billede, dvs. i billedet af skabersproget) og blev derved erkendende i det sprog, som Gud skabte i. Samtidig fik mennesket det sprog, som Gud havde skabt i som gave og blev derved i stand til at benævne tingene. Gud gav det sprog fra sig til mennesket, som alt, minus mennesket, selv er skabt af og erkendbart i, til gengæld blev mennesket skabt erkendende og benævnende. Derved forstås, at »[menneskets] åndelige væsen er det sprog, der blev skabt $\mathrm{i} \ll,{ }^{17}$ men menneskets sprog, det benavnende, er kun en refleks af skabersproget.

Menneskets åndelige væsen som sprog må således forstås som forskelligt fra dets benævnende sprog, men forskelligt som to sprogs forskellighed; to sprog, der aldrig kan nå hinanden umiddelbart og aldrig dække hinanden. Det nærmeste, de kan komme hinanden, er i egennavnet, og i menneskets benævnelse af tingene. Egennavnet har dog en særlig karakter, det modsvarer ingen 
erkendelse, det er nærmest en besværgelse. »Egennavnet er menneskets fællesskab med Guds skabende ord «. ${ }^{18}$ Tingene derimod blev skabt af Guds ord og erkendes gennem menneskets benævnelse med det sprog, som blev overgivet mennesket. Derved deltager det også i et »sprogfællesskab med Guds ord«, som Benjamin formulerer det, dog ikke så tæt som egennavnets fællesskab.

Alligevel er menneskets benævnelse i sproget ikke uindskrænket, spontant, men 'styret' af forlagget så at sige, af dets disponibilitet ville Barthes sige. Erkendelsen i benævnelsen er nemlig afhængig af, hvorledes tingen meddeler sig til mennesket. Det forholder sig nemlig sådan ifølge Benjamin, at den erkendelsesevne, som blev overgivet mennesket i sproget, for en dels vedkommende viser sig som receptivitet. ${ }^{19}$ Denne receptivitet må forstås som en særlig lydhørhed (sanselighed?) over for det meddelelige eller kommunikerbare i tingenes sprog, som mennesket erkender ved den menneskelige benævnelse. Der sker altså en »oversættelse af et ufuldkomment sprog til et mere fuldkomment «. ${ }^{20}$ Menneskets sprog føjer i henholdsvis receptiviteten af det kommunikerbare og i benævnelsen noget til, siger Benjamin, noget tingenes sprog manglede, nemlig navnet.

Men hvad er det så, mennesket benævner og erkender ved den proces? Det er ikke tingen som sådan, har vi erfaret, den kan vi ikke nå (efter syndefaldet), men den del af tingen eller tingens åndelige væsen, som lader sig meddele, dvs. dens sproglige væsen. Det er dens indrettethed mod at blive mere fuldstændigt eller gyldigt benævnt, kunne man måske sige. Benjamin kommer med et eksempel, som jeg tror mange kan nikke genkendende til: »Denne lampes sprog meddeler ikke lampen (thi lampens åndelige væsen, for så vidt det lader sig meddele er aldeles ikke lampen selv), men: sprog-lampen, lampen i en meddelelse, lampen i udtrykket «, ${ }^{21}$ lampen i sproglig udgave, ligesom modetøjet i modesprogets udgave, ${ }^{22}$ solen i poetisk udgave, Paris i Baudelaires udgave, etc.

Tingen har sit eget sprog, for så vidt den lader sig meddele. Dette sprog opfanger mennesket, for så vidt det (tingens eget sprog) er indstillet på at lade sig meddele (det må være en konsekvens, som Benjamin ikke synes at pointere tilstrækkelig tydeligt, men vigtigt i denne sammenhæng!), og i benævnelsen, dvs. oversættelsen til menneskesprog, tilføjer mennesket tingens sprog erkendelse.

Baggrunden for at forstå Benjamins generelle syn på umuligheden af at stå uden for sproget i en kommunikation af et åndeligt indhold er således uløseligt forbundet med forskellen mellem det åndelige væsen og det sproglige, benævnelsessproget (syndefaldet atter en gang). Det sproglige er kun identisk med det åndelige væsen i den udstrækning, det åndelige lader sig meddele. Et men- 
neske, der meddeler noget essentielt, i betydningen flytter et åndeligt budskab fra et sted til et andet, vil ikke kunne gribe om dette, hvis det åndelige budskab ikke selv lader sig meddele, dvs. hvis det ikke lader sig gribe som sprog, og det vil igen sige, hvis det ikke er indrettet mod at blive erkendt. Benjamin siger: »Der findes altså ikke en taler af sprogene, hvis man dermed mener én, som meddeler sig gennem disse sprog. Det åndelige væsen meddeler sig i et sprog og ikke gennem et sprog. $\cdot \ll^{23} \mathrm{Og}$ i forlængelse af ovenstående om receptiviteten, kan man vel tillade sig at forstå denne taler som den, der generelt set benævner, dvs. os alle, når vi forsøger at erkende i sproglig udfoldelse. Mennesket har godt nok fået overdraget den sproglige benævnerevne, vel at mærke $i$ en styret ikke i en 'vild' udgave, styret som den er af det, der lader sig benævne. Og - som Benjamin også gør opmærksom på til sidst - indirekte, som symbol på det, styret af det som ikke lader sig meddele. (Hvad det så er? Her kan man godt blive lidt urolig, for hvor meget er der af det, som ikke lader sig benævne i forhold til det, som indlader sig på at blive benævnt?) Men retningen eller målrettetheden i den meddelelighed eller kommunikerbarhed, som ligger i den sproglige laden sig benævne, er klar hos Benjamin.

Tingene meddeler sig til mennesket. »Det er ingen antropomorfisme. Dette svars sandhed viser sig i erkendelsen og måske også i kunsten. Desuden: hvis lampen, bjerget og ræven ikke meddelte sig til mennesket, hvor skulle det da kunne benævne dem $\ll .{ }^{24}$ Tingene kan dog også meddele sig til hinanden »via et mere eller mindre stofligt fællesskab $\ll .{ }^{25}$ Det virker dog lidt uklart, hvordan det skulle ske. Hvad er det stoflige fællesskabs forhold til deres skabelse ved Guds ord? Men da tingene er erkendbare i deres navne, i deres benævnelse, skulle det være muligt for menneskets særlige gudsindstiftede receptivitet at kode sig ind på denne interne kommunikation og 'forstå' i betydningen erkende den. Da tingenes sprog jo som nævnt er ufuldkomne, kan mennesket måske med sin erkendelse tilføre disse sprog mere fuldkommenhed, således at de bliver i stand til at oversætte hinanden fyldigere, fuldstændigere (dvs. mere dækkende) og gyldigere. Det vil betyde mindre frustration i den tingslige interne kommunikation. ${ }^{26}$

Mennesket meddeler sig til Gud. Eller mere præcist: i benævnelsen af tingene, meddeler mennesket sit åndelige væsen til Gud. Det er der for så vidt ikke noget at sige til, det er jo en slags tak for sidst. Ringen er sluttet. Hvem forstår mig bedre end den, der har skabt mig i sit billede, omend ufuldkommen så dog med (næsten) den samme skaberkraft? Men med denne sidste reference står hele tankegangen også i fare for at ende som en selvbekræftelse. Som Gud så, at hans eget skaberværk var godt, skal han nu også sanktionere menneskets. Det ligner en tautologi, som undlader at tage stilling til et væsentligt forhold. Da mennesket blev skabt, af materie, fik det ikke kun sproget, men også 
en krop. Men hvor er den blevet af i Benjamins menneskebillede? Det skal jeg vende tilbage til.

Benjamins egen understregning af, at det åndelige væsen er identisk med det sproglige væsen i den udstrækning, det er meddelbart, det lader sig meddele, forstået aktivt, skaber dog muligheden for at læse ham med Barthes og måske derved levere ham kroppen tilbage! Man kunne således hævde, at i Barthes' perspektiv, men stadig i solidaritet med Benjamins sprogforståelse, opsnappes bestræbelsen af et andet receptivt »sprogligt subjekt « (selv om den var rettet mod noget transcendentalt, f.eks. Gud), hvorved det førstes »åndelige væsen « i sproglig udgave tilføjes erkendelse gennem det andet sproglige subjekts benævnelse, ligesom når mennesket oversætter tingenes dunkle sprog til menneskesprog og tilføjer det erkendelse. Og så fremdeles: dette andet sproglige subjekts benævnelse opsnappes osv. I denne læsning bruger man hinanden som hinandens allegorier, modbilleder, antitese, hvor den egentlige syntese er om ikke at hente hos Gud og i den direkte konfrontation med Sandheden, så er den dog mere end den, som Benjamin levner den æstetiske betragtning, nemlig paradoksien i sørgespillet ${ }^{27}$ og mere end noget så spagt og antydende som billedet på en forhåbning, som er syntesen hos Goethe i Valgslagtskaberne ifølge Benjamin. Der har nu manifesteret sig noget, der ligner et eliotsk objektivt, konkret sprogligt korrelat mellem to menneskelige benævnere, der er indrettet mod gensidigt at oversatte »bestræbelsen efter at sprede tågen af de symbolske relationer, der udgør den som et mytisk væv - eller for nemheds skyld: som en tekst «. ${ }^{28}$ Benævnelsens orientering mod den absolutte referent på den ene side og dens orientering mod et andet sprogligt subjekt på den anden side er måske den afgørende forskel mellem Benjamin og Barthes.

Roland Barthes' forhold til sproget er også konkret, men mere pragmatisk. Det er sproget som et faktum, et magtfuldt faktum knyttet som det altid er til selve udsigelsessituationen og mulighederne for at omgå denne umiddelbare magtfuldhed ved hjælp af sprogets egen indbyggede tøven eller dobbelthed, der optager ham.

En indgang til at forstå dette kunne være at blive klar på, hvad Barthes egentlig sagde, og hvad det var, der satte sindene så meget i kog, da han i 1964 tog Saussure på ordet og luftede muligheden for, at lingvistikken »en dag « ikke blot skulle forstås som »patron géneral de toute sémiologie $\ll,{ }^{29}$ som Saussure havde betegnet den, men som overbegreb for semiologien, sådan at forstå at videnskaben om tegnene da kunne betragtes som værende en del af en videnskab om sproget:

»Kort sagt må man nu regne med muligheden for en dag at ombryde Saussures læresætning [således at forstå at] lingvistikken ikke er en del 
af den generelle videnskab om tegn, end ikke en privilegeret del, det er [derimod] semiologien, som er en del af lingvistikken: helt præcist den del som ville tage sig af diskursens store betydende enheder; på den måde ville enheden i den forskning omkring betydningsbegrebet, som netop nu finder sted inden for antropologi, sociologi, psykoanalyse og stilistik, komme til syne.$^{30}$

Allerførst må vi have slået fast, at det hos Barthes ikke drejer sig om at afgrænse sprog i forhold til tegn, altså om der findes tegn, der ikke er sprog, eller omvendt. Altså om dyrene kommunikerer med hinanden ved hjælp af noget, vi mennesker vil kalde tegn. Eller om ting kan være tegn for hinanden. Eller sågar om noget levende kan være tegn for noget ikke-levende, hvad enten det har været levende eller ej. Tegn kan kun være tegn som tegn for noget eller nogen. Det må være klart, noget eller nogen, altså ikke nødvendigvis et menneske. Noget kan blive eller være tegn for nogen eller noget. Uendelige eksempler på det i naturen og blandt mennesker (og i øvrigt også $i$ mennesker, somatisk og psyko-somatisk betragtet ${ }^{31}$ ). Altså: kvaliteten sprog er indeholdt $i$ kvaliteten tegn. - Det er det, det ikke drejer sig om. Det, som det her udelukkende drejer sig om, er, om sprogvidenskaben er en del af tegnvidenskaben eller omvendt. Det er på det plan, Barthes har udtalt sig, og ikke om der findes tegn, der ikke er sprog, eller om alle tegn er sprog.

Skismaet hænger tilsyneladende sammen med forrykkethedsproblematikken, som jeg tidligere har været inde på. Vi reflekterer i og med sproget og kun der. Kun i sproget (og her tænker jeg altså kun på menneskets dobbeltartikulerede verbalsprog, og ikke på nogen anden forståelse af begrebet sprog, metaforisk eller 'semiologisk') forstår vi os selv som forrykket i forhold til en eller anden oprindelighed eller begyndelse, som individ og som art. Det må vist være det, man kalder den 'sprogfilosofiske' udgave af syndefaldsmyten. I den forståelse er al anden tegngivning ikke refleksiv, den kan ikke fundere over sig selv, den kan f.eks. ikke være selvironisk. Naturens tegn ser f.eks. ikke noget formål i at udtrykke tvivl, hvorfor skulle de det? Det kan godt være, at vi synes, at de gør det, og så gør de det, men de ved det ikke selv! Naturen ved ikke noget, det er menneskene, der ved. Og vi ved i og med vores tale og skriftsprog. Hvad er det så for en viden, vi besidder, som den $\emptyset$ vrige natur ikke besidder? Det er den viden, vi har i kraft af sproget og ikke andet. Viden og sprog er to sider af samme sag. Men ikke nok med det. Da sproget er uløseligt forbundet med vores væren anderledes, er vores viden det også. Eller vores viden er forbundet med vores forrykkethed i forhold til den $\emptyset$ vrige natur, på samme måde som sproget er det. Ydermere ved vi, at vi ved, men også kun i kraft af sproget. Denne potensopløftning er der ingen ende på (en verbal mise 
en abîme). Kun naturen sætter grænsen, enten som magt eller som træthed. Ud fra den position er viden om sprog, sprogvidenskab, lingvistik overordnet viden om tegn, tegnvidenskab, semiologi (semiotik).

Barthes formulerer sig i 1977 om forholdet på denne måde:

»Semiologien, der kanonisk kan defineres som videnskaben om tegnene, alle slags tegn, er ved sine operationer begreber udgået fra lingvistikken. Men lingvistikken selv er, forekommer det mig, ... ved at blive sprængt, indefra: på den ene side drages den mod en formel pol, og ifølge denne tilbøjelighed bliver den ... mere og mere formaliseret; på den anden side bemægtiger den sig flere og flere indhold, der ligger længere og længere borte fra dens oprindelige felt ... i det politiske, i det sociale, i det kulturelle, således er ... lingvistikkens genstand uden grænser: sproget er, som Benveniste indså, selve det sociale (m. fr.). Kort sagt, overmål af askese eller overmål af sult, tynd eller tyk: lingvistikken er ved at blive dekonstrueret. Det er denne dekonstruktion jeg for min part kalder semiologi. $\ll^{32}$

Benveniste forstår sproget som selve det sociale, (»overbevist med Benveniste om at al kultur udelukkende er sprog) «. ${ }^{33}$ For Roman Jakobson er sproget centrum for alle menneskelige, semiotiske systemer og det vigtigste blandt dem. ${ }^{34}$

Men der er endnu en hurdle ved alt her, og det er måske det væsentligste ved hele sprogforholdet, når vi taler om Barthes. Når sprogsystemet vil forstå sig selv i rationel forstand, vil danne viden om det, det selv siger, vil denne viden desværre aldrig kunne blive udtømmende (det har Gödel ${ }^{35}$ (næsten) bevist), selv om man umiddelbart skulle tro, at sproget skulle kunne komme tættere på sig selv end de andre 'fremmede' tegnsystemer. Til gengæld ligger der en udfordring $i$, at det forholder sig sådan. At man kun kan nærme sig asymptotisk til sig selv og sin kommunikationspartner igennem sprog. Hvis man vil tage denne udfordring op, støder man på det 'vi', som hele tiden skal forstå eller vide eller kommunikere. I tegnvidenskaben og i sprogvidenskaben har det som sagt kun sproget at udfolde sig i. Så på en eller anden måde må dets status som sprogudfoldet 1. person, 'jeg' eller 'vi', medindregnes.

Vidensdannelse og -kommunikation er det, vi taler om, når vi taler om tegnvidenskab og sprogvidenskab. Men det foregår altid via et 'jeg' eller et 'vi' dakkende såvel skribent- som laeseraspektet af kommunikationen. Dette 'jeg' eller 'vi', der forstår og danner viden, er selv tegn i et tegnsystem, der som videnskab kun kan forstås i sprog. 'Jeg' eller 'vi' kan altså ikke stå uden for sproget i en videnskabelig diskurs. En videnskabelig diskurs om et hvilket som helst tegnsystem, incl. sprogsystemet, må altså være en udsigelse, der 
indbefatter 'jeg' eller 'vi'. En videnskabelig diskurs kommunikerer altså samtidig med vidensudfoldelsen i kraft af en 'selv'-fremstilling, hvortil erkendelsen er knyttet. 'Selv' forstået som et aktivt subjektperspektiv og netop ikke som et subjekt i enhedslig forstand. En analyse eller videnskabelig diskurs kan således være enten subjektivt tolkende med en metaforisk relation til analyseobjektet, eller selv-fremstillende med en metonymisk relation til det diskursen fremstiller.

Det forekom Barthes vigtigt at tage denne udfordring op. I gængs videnskabsforståelse er der en tendens til, at dette forhold behandles for sig selv, som et selvstændigt forskningsområde inden for psykoanalysens rammer. Det medreflekteres sjældent i videnskabelige diskurser i det hele taget. Sådanne medrefleksioner er støj på linjen, forstyrrende for den 'objektive' rent kommunikative brug af sproget, man er i gang med. Det er denne indsigt Benjamin og Barthes synes at dele til fuldstændighed. Goldbæk sammenfatter Benjamins synspunkt således:

»Erkendelse hos Benjamin er ene og alene bundet til fremstilling som selv-fremstilling, altså til begrebet som formidler af det ikke-subjektive, af navnesproget, tingenes utopiske status uden for den subjektivt dømmende sprogsfære. For Benjamin er den vigtigste erkendelseskritiske forudsætning altså, at videnskaben generhverver sin mimetiske side. Med mimetisk mener han ikke efterligning af det faktiske, men af det autentisk-mulige og ikke realiserede, af det virtuelle i historien og tingene ${ }^{36}{ }^{36}$

Det virker da også, som om at det er gennem Benjamins tanker om sprogets meddelbarhedskvalitet og om investeringen af oversatteligheden i teksten eller bestræbelserne på samme i forbindelse med etableringen af symbolske eller allegoriske profetier, at en person som Barthes ville finde (finder) genlyd for sine tanker om at forstå sproglig udsigelse ud fra en indbefatning i 'selv'-fremstillingen af det, man kunne kalde »meddelbarhedens « reversibilitet og ikke ud fra en udgransning af kommunikationens referencepunkter. Dette er tekstualitetens (Barthes: »Tekstens «) intentio sine qua non, ${ }^{37}$ måtte den være opfattet som videnskabelig eller ikke:

»Jeg tror ikke længere - og jeg ønsker det heller ikke - at Semiologien skal blive en simpel videnskab, en positivistisk videnskab, af den væsentlige grund, at det tilkommer semiologien, og måske i dag netop Semiologien af alle humanvidenskaberne, at indbefatte sin egen diskurs i det studerede område, som er videnskab om sproget, om sprogene. Se- 
miologien kan ikke acceptere sit eget sprog som værende blot en given størrelse, som noget gennemsigtigt, et værktøj, kort sagt et meta-sprog. Psykoanalysens styrke er, at den udspørger sig selv om, hvorfra den taler, en udspørgen uden hvilken enhver videnskab eller enhver ideologisk kritik er hånlig. Ifølge Semiologien, det håber jeg i det mindste ikke, eksisterer der ikke noget ydre rum (»exterritorialité«) for subjektet m.h.t. dets diskurs, selv ikke for forskeren, eller sagt på en anden måde, videnskaben har ikke helle nogen steder, og af denne grund må den vedkende sig sin egen skriven. $\ll^{38}$

Barthes betagtede dette spørgsmål som et spørgsmål om videnskabelig moral. Han betegnede en videnskab, med Nietzsches ord, for en adiaforisk videnskab, en indifferent videnskab, når den holder sin egen talen eller skriven og tilskyndelsen hertil uden for sin diskurs. Han siger herom i 1977, så der ikke for nogen længere er tvivl, heller ikke for ham selv:

»Hvis det er sandt, at videnskabens subjekt er det subjekt, der ikke stiller sig til skue, og at det i grunden er denne holden skuespillet udenfor, vi kalder 'meta-sprog', så er jeg, når jeg vil tale om tegnene med tegn, tvunget til at se netop dette løjerlige sammentræf i øjnene, tvunget til at påtage mig denne mærkelige skeløjethed, der bringer mig i familje med de kinesiske skyggespillere, som på én gang viser deres hænder og den kanin, and, ulv, hvis silhuet de simulerer. Og hvis nogen udnytter den betingelse til at frakende den aktive, den skrivende semiolog enhver forbindelse med videnskaben, må man gøre dem begribeligt, at det var en epistemologisk misforståelse som netop nu begynder at forvitre, når vi satte lighedstegn mellem metasprog og videnskab, som om den ene var en nødvendig betingelse for den anden, skønt den kun er dens historiske altså anfægtelige kendetegn; det er måske på tide at skelne metasproglighed, der er et mærkat som ethvert andet, fra videnskabelighed, hvis kriterier findes et andet sted. $\ll^{39}$

Tekstualitetsteorien synes således med Benjamin at have fået endnu en proselyt, retrospektivt så at sige. Men det kræver en forklaring, for 'tilslutningen' er ikke fuldstændig. Barthes og Benjamin mødes kun i sproget og i litteraturen, fordi deres veje krydses der, men deres mål var ikke de samme. Og det er interessant af flere grunde. Dels fordi det åbner for en sprog- og historiefilosofisk perspektivering af Barthes' litteratur- og læsebegrebsmæssige positioner, som andre har været temmelig karrige med at give, ${ }^{40}$ angiveligt fordi han har været relativt underspillet i refleksionerne på de områder af sin egen pro- 
duktion, der ikke knyttede an til den rimeligt accepterede strukturalistiske trend og uden tvivl også pga. diverse magtkampe i det universitære miljø. ${ }^{41} \mathrm{Og}$ så selvfølgelig fordi han også havde andre energier og ambitioner forbundet med det at skrive og arbejde med sproget. Det lå jo i forlængelse af det syn, han havde på sproget og sprogets funktionelle roller.

Omvendt er det interessant fordi sammenholdningen af Barthes og Benjamin accentuerer, aktualiserer og om nødvendigt demystificerer Benjamins sprog- og historiefilosofiske teser. Lad mig blot minde om følgende teser af Benjamin: »I hver epoke må det fors $\emptyset$ ges på ny at vriste overleveringen fra den konformisme, der er i færd med at underlægge sig den« eller »At artikulere fortiden historisk betyder ikke at erkende, 'hvordan det virkelig er sket'. Det betyder at bemaegtige sig en erindring, der slår ned i farens stund $\ll .{ }^{42} \mathrm{Med}$ Barthes' profetier om en videnskab om sproget som en overordnet og samlende refleksionsform for andre videnskaber og med hans påpegning af, at indsigten, gyldigheden, sandheden kun kan fastholdes i (endnu) en i traditionel forstand ikke-metasproglig diskurs, synes Benjamin at have fået støtte for en væsentlig del af sin selv-fremstillingsteori, som beskrevet ovenfor.

\section{Litteraturen som på én gang et oprindelsens og et utopiens sted}

På trods af disse nok så forskellige tilgange til fænomenet sprog, synes Barthes og Benjamin begge at være optaget af den samme væsentlige kvalitet ved sproget, nemlig dets umiddelbare meddelbarhedsevne og dets nærhedsrelation til det, som det fremstiller. Derfor er der interessant at undersøge, i hvor høj grad de kunne tænkes at kvalificere og supplere hinandens synspunkter.

For lige at rekapitulere så har sproget i hvert fald to funktioner, nemlig dem vi kaldte den pragmatiske og den utopiske. Den pragmatiske fremstiller den praktiske virkelighedsforståelse og virkelighedsbestræbelse, og den utopiske fremstiller forestillingen om en frihed i umiddelbar og uformidlet forståelse af menneskets liv i og med virkeligheden. Altså en insisteren på sprogets utopiske funktion i sameksistens med den pragmatiske. Dog er »utopien ... naturligvis ingen garanti mod magten «, som Barthes siger, »sprogets utopi genindlemmes som utopiens sprog - der er en genre som enhver anden $\ll{ }^{43}$ For Barthes er utopi ikke lig med noget principielt uopnåeligt eller transcendentalt i forhold til virkeligheden, men snarere en sproglig synliggørelse af det, der ellers ikke kan siges eller blive taget for givet (f.eks. 'naturligt'). For Benjamin 
ligger der i den sprogligt fremstillede utopi en stræben efter en endelig sandhed hinsides endeligheden.

Et af problemerne kunne derfor være: Hvordan lever vi med to sprog på én gang, hvordan lever vi med samtidig tilstedeværelse af endeligheden og uendeligheden?

Tilsyneladende sker det i produktiv komplementaritet (eller forsoning). Vi kan godt fungere med mangfoldigheds- eller uendelighedssystemer. Vi kan jo alligevel ikke overskue uendeligheden. Men det betyder ikke, at vi fornægter deres eksistens. Jeg kan udmærket se på stjernerne og nyde det uden at forsvinde ud i det uendelige verdensrum. Min fysiske endelighed begrænser min skuen, men uendeligheden lever videre både der og her i mig og påvirker, hvad jeg siger og gør, som om jeg ikke var begrænset. Mit synsfelt er begrænset, men min krop som sådan deltager i uendeligheden og bidrager til min erfaring. Både endelighed og uendelighed er mit erfaringsgrundlag. Med begge ben plantet solidt i denne verden og uden at være forlovet med dens begrænsede udsyn, overskrider erkendelsen ikke erfaringen, men erfaringen overskrider empirien. Derfor kan utopien sættes i værk her og nu af ethvert såkaldt sprogligt subjekt, der i sin sproglige udfoldelse giver betydning til det selvfølgelige og benævner det navnløse. På den måde sættes litteraturen jo selvfølgelig som det utopiske sted par exellence. For Barthes i en asymptotisk tilnærmelsesbestræbelse af sprog og virkelighed. For Benjamin som det sandhedens skyggespilteater vi opfører med de billeder og brokker, vi måtte være i besiddelse af.

Barthes og Benjamin mødtes fra hver sin side i en forståelse af, at ny erkendelse kun opnås i en antitetisk dynamik, en dialektik med den diskurs, der har etableret sig. Hos Barthes ofte benævnt doxa (gr. for mening, antagelse). Det er den, han f.eks. tager under myteanalytisk behandling under overskriften »Petite mythologie du mois « i 50'erne i bladet Lettres Nouvelles (senere udgivet i uddrag i bogen Mythologies (1957)). Men overalt, hvor Barthes arbejder, både læser han denne dialektiske svingning mellem doxa og paradoksa, ${ }^{44}$ mellem 'billede' og 'modbillede', i teksten og praktiserer den selv i sin egen skriven. Således hans læsning af bl.a. Racine, Balzac, Poe, Flaubert, Proust og mange andre. Han forklarer sig selv (med det sociale i fokus) på følgende måde:

»Forklaringsprincip: dette værk svinger mellem to termer: - ved den oprindelige term findes de sociale forholds uigennemsigtighed. Denne uigennemsigtighed har fra starten åbenbaret sig i stereotypens tyngende form (skolestilens obligate figurer, de kommunistiske romaner i Litteraturens Nulpunkt). Siden da, tusind andre former af Doxaen; 
- ved den finale (utopiske) term, findes transparensen: den blide følelse, $\emptyset$ nsket, sukket, begæret efter et hvil, som kunne den sociale samtales konsistens en dag klares, lettes, gennemhulles til det usynlige.

1. Den sociale deling skaber uigennemsigtighed (tilsyneladende paradoks: dér hvor det socialt er meget delt, synes det uigennemsigtigt, massivt).

2. Subjektet kæmper mod denne uigennemsigtighed, på alle de måder, det kan.

3. Men hvis han selv er et sprogligt subjekt, (m. fr.) kan hans kamp ikke direkte få en politisk løsning, for det ville være at genfinde stereotypernes uigennemsigtighed. Denne kamp bliver altså apokalyptisk i sin bevægelse: han deler i det ekstreme, han udpiner et helt sæt af værdier, og samtidig lever han utopisk - kunne man sige: han indånder: de sociale forholds finale transparens. $\ll^{45}$

Dvs. på baggrund af en uigennemsigtighed (tesen 1.) skabes (anti-tesen 2.) en transparens (utopien eller syntesen 3.). Anti-tesen er selve den aktive modstillen. Dvs. både den sproglige læsning af den indre dialektik (hvis den er der, det kan jo være rent doxa det hele! Eller med Benjamins ord: hvis den lader sig meddele) og udfoldelsen eller fremstillingen af denne læsning i en ny tekst el. lign. Benjamin gjorde jo, som vi husker, en del af den menneskelige skaberkraft til en receptivitet. ${ }^{46}$ Hos Benjamin ligger dynamikken i det allegoriske modspil til det fastlagte og det allerede forudbestemte, som han viser det bl.a. i sørgespilsbogen og romantikanalysen. ${ }^{47}$

Men hvad med (litteratur)videnskaben? Er den indstillet på at udfordre virkeligheden - på sprogets præmisser (for heller ikke den kan vel undslå sig sin sprogrolle)? En reaktion kunne være, at hvis videnskaben ikke skal stille sig tilfreds med den analoge vidensdannelse (og myterne herom), som den pragmatiske sprogrolle befordrer, må den finde en form, hvori den kan tillade sig selv at tænke i andre spor end dem, som andre sprogbrugere har lagt ud. Ikke forstået sådan, at man ikke skal forholde sig til dem, det er netop det man skal, man kan sådan set heller ikke andet. Men sådan at forstå at man medtænker projektionen af sit eget udgangspunkt (f.eks. sprogbrugskoder ${ }^{48}$ ) i forståelsen af det objekt, man undersøger. Steinhagen formulerer Benjamins synspunkt på en måde, som bringer tilsvarende af Barthes i erindring:

»... når projektioner ved al beskæftigelse med litteratur, også den videnskabelige, uundgåeligt er på spil - og sætter dens videnskabelighed i tvivl - så nytter det ikke noget at lukke øjnene for dette faktum, i den tro at det kan elimineres af en metodisk objektiv fremgangsmåde; så er 
overvindelsen af den blotte betydningsprojektion på genstanden, som visselig ikke kan gælde for videnskabelig erkendelse, kun tænkelig, når man bevidst anerkender projektionen som uundgåelig, sådan som Benjamin til stadighed gjorde; så kan man kun vedgå dens uundgåelighed og samtidig håbe på erkendelser, der gør genstandene fyldest, hvor altså de forudgående projektioner er brudt. For Benjamin er derfor al fortolkning, al tekstudlægning og al kritik først og fremmest allegorese, der ligesom den antikke Homer-allegorese tillægger teksterne sine egne betydninger, som indprojicerer sine subjektive anskuelser, forestillinger og opfattelser i genstandene. Den står dermed på samme trin som for-forståelsen i den hermeneutiske fremgangsmåde, som fremstiller et første, subjektivt udkast til mening, der så i den videre procedure skridt for skridt bliver afløst af en sagsrettet forståelse, som samtidig selvkritisk korrigerer forforståelsen eller virtuelt bliver til kritik af genstanden. $\ll^{49}$

Forskellen mellem den rene analoge videnskab (eller litteratur for den sags skyld), den der påtager sig den pragmatiske maske (uden at vide det er en maske), og den antitetiske, den der påtager sig den utopiske maske (og hele tiden peger på den) er fundamental. Den første er utopisk bagudrettet, kan man sige, og den anden er utopisk fremadrettet. Utopisk bagudrettet fordi dens forestilling om Oprindelsen er en naturaliseret Begyndelse (beslægtet med Sandhedsbegrebets entydighedspræg i $\emptyset$ vrigt) og fortoner sig ud i al fortid. Den antitetiske videnskabskonception derimod forestiller sig, at erkendelsen (indsigten, transparensen, forandring til det bedre) ligger immanent i selve den sproglige dynamik. Tilværelsen må derfor hele tiden 'skabes på ny' for at blive forstået og accepteret. Snarere beslægtet med Benjamins Ursprung-begreb ${ }^{50}$ her i Goldbæks sammenfatning: »Ursprung betyder den fuldstændige erkendelse af en begivenhed set fra slutpunktet, fra den færdige proces. Men Ursprung betyder også denne proces i dens videre, fremtidige, endnu ikke erkendte forløb hen mod en utopisk realisering ${ }^{51}{ }^{51}$

For al videnskab er udgangspunktet væsentligt. Hvorfra betragtes fænomenet, i hvilket perspektiv, hvad tages for givet, karakteren af dynamikken i fænomenet etc. Derfor er et begreb om oprindelse væsentligt. Begge videnskabsperspektiver forholder sig eksplicit til forestillingen om oprindelse og dynamik. Den førstes bagudrettede utopi har at gøre med den særlige mytiske form for opfattelse af oprindelse, der ligger bag dens videnskabsopfattelse, og som sætter den i kontrast til den antitetiske videnskabskonceptions forestilling om oprindelse, som kan knyttes til modbegrebet opståen (Benjamin: »Entstehung «), det skabtes tilblivelse, eller som sagt til begrebet Ursprung, alt efter hvor perspektivet lægges. 
Der synes at ligge en naturvidenskabelig inspireret opfattelse af livets begyndelse, i naturaliseret mytisk udgave, bag tendensen til og behovet for afrunding og afgrænsning, som man møder den i den diskurs, der ynder at konkludere, resumere, 'fastlægge, hvor vi er nået til', appellere til 'det rimelige i at betydningen af dette eller hint fænomen må bestemmes til at være' sådan og sådan, 'for at vi kan vide, hvor vi står' etc. Denne form for mytologisering af Oprindelsen adskiller sig fra de fremadrettede utopiske skabelsesmyter, som vi har under behandling her, bl.a. ved at være 'ordløs', dvs. ved blot at betragte sproget som redskab. I det pragmatiske begreb om Opståen er perspektivet hele tiden: verden set udefra. Individet, mennesket opstår og bliver defineret (benævnt) i forhold til dets umiddelbare omgivelser (i forhold til alt andet er det udefinerligt). Det får således et sprog, som det kan anvende til at forstå hinanden og den omverden med, som definerer det. Sådan er det, sådan bliver individet og tingene til i et intrakontekstuelt kausalsystem. Sproget er et redskab som alle mulige andre redskaber. Det har sin funktion, det er defineret $\mathrm{i}$ forhold til det, det skal bruges til, som alle andre ting er. Dets betydning er bestemt af relationer til omgivelserne, dvs. de peger på dem som tegn for dem. Alt bliver defineret ved at være tegn for hinanden. Sproget, sprogets bestanddele, menneskene, ting, alt i naturen. Alt holder ligesom hinanden fast i en skruestik. Alt klamrer sig til hinanden i en gensidig forståelse for og af hinanden, som reddet af en angst for det store tomme tegn- og ordløse rum uden om.

Den naturvidenskabelige kausallogik, som vi ud fra de fysisk-kemiske love forstår naturen med, er i mange henseender uden tvivl adækvat, som man siger, konform med de faktiske forhold. Men den kan bare ikke forklare menneskets bevidste (og ubevidste) måde at opfatte, erfare og forstå omverdenen på lige så adækvat (dvs. gyldigt). For at få en samlet forståelse af menneskelivet og naturen må den suppleres med en epistemologi, der med det konkrete menneske som udgangspunkt på adækvat vis lever op til den sprogbaserede semiosis-logik, som vi nu engang betjener os af, for vi kan ikke andet, når vi søger sandheden. »Ideen er noget sprogligt og givetvis altid det moment ved ordets væsen, i hvilket det er symbol «. ${ }^{2}$ Barthes siger - som talt ud af Benjamins mund:

»... Oprindelsen er en af Naturens (af Fysis') skadelige figurer: ved en beregnet fejlslutning 'presser' Doxaen Oprindelsen og Sandheden sammen for at gøre dem til ét bevis, hvor de hver især på skift nok så bekvemmeligt kommer hinanden til undsætning: er de humanistiske videnskaber ikke etymologiske i deres søgen efter alle tings etymon (oprindelse og sandhed)? $\ll^{53}$ 
Og videre for egen regning og risiko i en slags selv-kommentar:

»For at modvirke Oprindelsen kulturaliserer han [Barthes selv] først fuldstændigt Naturen: intet naturligt noget steds, kun noget historisk; denne kultur (overbevist med Benveniste om at al kultur udelukkende er sprog) genindsætter han dernæst i diskursernes uendelige bevægelse, den ene anbragt oven på den anden (og ikke frembragt), som i pandekagelegen [den med hænderne skiftevis oven på hinanden] ${ }^{54}$

Den logik har ikke udgangspunkt i tidernes morgen, men i dagen i dag. Dagen i dag og ethvert af historiens nu'er er den faktiske oprindelse, det faktiske udgangspunkt for al erkendelse. Vores nu er en nedsmeltning af alle andre nu'er. »Oprindelsen står midt i tilblivelsens strøm som hvirvel og river tilblivelsesmaterialet ind i sin rytme $«{ }^{55}$ Barthes forklarer hvori denne 'nedsmeltning' består med en beskrivelse af sit eget projekt og 'hvor han står i dag'.

Barthes blev en gang af en student bedt om at komme med nogle kommentarer til et projekt, hun havde kaldt »En ideologisk kritik af semiologien «. Det provokerede ham så meget, at han fandt anledning til at redegøre for, hvad Semiologi som videnskab var for ham selv. Meget kort delte han sit liv med Semiologien ind i tre perioder med overskrifterne Håb, Videnskab og Tekst. Den første fase var domineret af forsøget på at samarbejde lingvistikken, eksistentialismen og marxismen til et ideologikritisk håbefuldt demaskeringsprojekt. Den anden fase var domineret af en forestilling om, at semiologien havde en fremtid for sig inden for videnskaben, da han fandt ud af, at det snarere var systematikken i foretagendet, der stimulerede ham, og semiologien havde en mere spændende fremtid uden for videnskaben, men i »et tjenestepigeforhold (!) til visse videnskaber «, som han senere formulerede det. Den tredje fase var domineret af det begreb om Teksten, som opstod omkring Kristeva, Lacan, Foucault, Derrida og Tel Quel-gruppen. Det var baggrunden. Nu til billedet. Da Barthes skulle forklare, hvor han stod »i dag«, svarede han følgende:

»Man fortæller at Louis d. 18., som var en kongelig gourmet, fik sin kok til at tilberede for sig adskillige koteletter stablet oven på hinanden, hvoraf han kun spiste den underste, som på den måde havde fået den saft, der var filtreret igennem de andre. På samme måde ville jeg gerne have, at den nuværende stund af mit semiologiske eventyr [fransk: aventure beslægtet med advenir: ske, hænde, 'hvad der kommer til mig'] måtte modtage saften fra de tidligere - og at filtret, som i de kongelige 
koteletter, måtte blive vævet af den samme substans, som blev filtreret, at filtratet måtte være selve filtret, ligesom indholdet er udtrykket - således at man i mit nuværende arbejde ville genfinde den drift, som havde animeret alt det forgangne i dette semiologiske eventyr: viljen til at forbinde mig selv med et fællesskab af rigoristiske forskere, og loyaliteten over for en hårdnakket sammenhæng mellem det politiske og det semiologiske. $\ll^{56}$

\section{Fremstilling og litteratur}

I det følgende vil jeg beskæftige mig mere indgående med de litterære og litteraturbeslægtede fremstillingsformer og se på, hvorledes de på den ene side formidler interaktionen mellem Benjamins og Barthes' sprog- og benævnelsesteorier og på den anden side mellem skribentrollen og læserrollen. Der vil dog ikke her blive plads til at gå nærmere ind i en præsentation og diskussion af det særlige syn på modtageren eller læseren af et kunstværk, som kommer til udtryk i »Die Aufgabe des Übersetzers «, ${ }^{57}$ og i Benjamins sprogfilosofiske skrifter. Heri betragtes læsersubjekt- eller recipientpositionen ud fra den grundlæggende sprog- og benævnelsesfilosofi, som er præsenteret ovenfor, og som har vist sig at være beslægtet med Barthes’ læsningsteorier.

Som Peter Collier rigtigt gør opmærksom på i den lille opsats »Roland Barthes: the critical subject (an idea for research) «, ${ }^{58}$ ligger der overalt hos Barthes, også - hvis man ser godt efter - i de tidlige Mytologier, ${ }^{59}$ en utilpashed ved den blotte strukturelle myte- og ideologikritiske analyse af de behandlede 'hverdagslivets bevidsthedsprodukter', som de blev betegnet. I Barthes' tekst, både i mytologierne og i den efterstillede »Myten i dag «, støder vi på et kritisk, aktivt subjektperspektiv, hvis benævnelser og betragtninger langtfra fyldestgørende kan forklares med den strukturalistiske mytemodel, som Barthes opstiller. Mytologiernes 'fortæller' er ikke et blot naturaliseret jeg-objekt, der lader sig manipulere til en bestemt forventet reaktion ud fra analysens strukturelle fastlæggelse af, hvordan teksten de facto er skruet sammen og fungerer. Mytologiernes 'fortæller' er det aktive læser- og betragtersubjekt, som på denne måde tidligt i forfatterskabet giver sig tilkende, men som vi møder i en mere ekspliciteret udgave, efterhånden som Barthes slipper ambitionerne på det strukturalistiske felt.

Lysten, glæden og det, der er stærkere, ved læsningen (i bred forstand), sætter sig igennem som perverteringen af det system, som teksten umiddelbart manifesterer, men - og det er afgørende - det sker på opfordring eller invitation fra teksten selv. ${ }^{60} \mathrm{Og}$ disse invitationer får vi generelt flere og flere af og 
bliver mere og mere lydhøre overfor i moderne tid, dvs. fra midten af attenhundredetallet og fremefter. ${ }^{61}$ Dette gælder ikke mindst som følge af det tiltagende ubehag ved det kapitalistiske samfunds hypostasering og naturalisering af jeg'et. Det har meningsfuldt kunnet forklares, som af Barthes selv, inden for en freudiansk-lacansk forståelsesramme, ${ }^{62}$ men kan givet suppleres med de Benjaminske begreber om erkendelse gennem fremstilling som tingenes (og altså også sprogets) selv-fremstilling, ledende frem til en kritisk teori om fortæller- og læsersubjektet, som Benjamin således leverer et grundlag for i sine sprogfilosofiske og litterære studier fra barokkens sørgespil over bl.a. Goethe, Baudelaire og Lesskow til Proust.

Dialektik og allegori. Litteraturen er eller kan være en sådan selv-fremstilling. Tekstualiteten er det. Det er dens bestemmelse, dens modus vivendi. Set i dette lys er det ikke så mærkeligt, at Benjamin og Barthes begge henholder sig til Hegels dialektik, selv om de divergerer i opfattelsen af syntesens karakter og status. Ja, i sin yderste konsekvens ophæves den for dem begge. For Benjamin bogstavelig talt i ideen, syntesen kan aldrig repræsenteres (i symbolet f.eks.) kun præsenteres, mod-billedligt. For Barthes i fremstillingens subjektfortabelse og diskursivitet, i bevægelsen mod le neutre.

»Som modsætningens figur, binarismens skærpede form, er antitesen selve meningens teater. Man kommer ud af det: enten ved det neutrale (m. fr.) eller gennem udgangen til det reelle (m. fr.) (den fortrolige hos Racine vil ophæve den tragiske antitese, Sur Racine: 61), eller ved hjælp af supplementet (Balzac supplerer antitesen hos Sarrasine, S/Z: 33), eller ved opfindelsen af en tredje (afledende) term. ${ }^{63}$

Et eksempel på dette meningens antitetiske teater kunne være Goethes mytiske skyggespil, som det fremstilles i romanen Valgslagtskaber. ${ }^{64}$ I Benjamins manuskript til sin bog om Goethes Valgslagtskaber ser vi i dispositionen inddelingen: »Første del: det mytiske som Tese ... Anden del: Forløsningen som Antitese ... Tredie del: Håbet som Syntese «. ${ }^{65}$ Modsætningen mellem det mytiske og forløsningen krydses hos Benjamin i denne analyse med begrebsparret »Sachgehalt « og »Wahrheitsgehalt«, som med Goldbæk er henholdsvis det konkrete mønster i romanen og urbillederne.

»Mellem idéplan [Wahrheitsgehalt] og ydre tegn [Sachgehalt] er der en afgrund. Det vil igen sige, at det konkrete, empiriens ting er blevet uigennemskuelige gåder og gester - de kan ikke uden videre relateres til en helhed: 'Er mennesket sunket ned på dette stade, så får selv døde 
tings liv magt. Et kriterium for den mytiske verden er jo netop denne inddragelse af samtlige ting i livet' (Benjamin: $U d d T$, p. 139).$^{66}$

Benjamin læser eksplicit en antitetisk struktur i romanen, sådan at forstå at hovedhistorien eller rammen læses mytisk (som tesen) og opfattes som Sachgehalt, mens romanen selv i øvrigt, stærkest i en indlagt novelle, giver billeder på ideen (antitesen), som opfattes som Wahrheitsgehalten. Pointen skulle i første omgang være, at mens livets sagsforhold kan fremstilles direkte konkret (men stadig som skyggespil, i kostymer), kan sandhedsforholdene kun vises i modbilleder. Nu forholder det sig sådan, at det antitetiske kan optræde i forskellige forklædninger. Allegorien kan deltage i modsatningsspillet i større eller mindre afklarethed. I Valgslaegtskaberne er der flere eksempler på dette. Jeg skal ikke her gå ind i en egentlig analyse af romanen, men blot pege på den indlagte novelles relative afklarethed i forhold til flere af de mere smertefulde billeder i rammehistorien. Dagliglivet, socialiteten betragtes indefra som skæbne, men af fortelleren Benjamin, som Goldbæk kalder ham, »som et mytisk skyggespil i goethetidens kostymer fremtræder dens indhold «.67

Under alle omstændigheder er det dagliglivet, socialiteten selv oplevet som skæbne, der bærer ved til bålet, dvs. til håbet om sin egen undergang. Den bygger op i den modvillige måde den bryder sammen på. »Kun med håbløshedens vilje er der givet os håb « ${ }^{68}$ Syntesen i semiotisk udgave. Eller med Barthes' ord: »Litteraturen er som fosfor, den lyser stærkest i det øjeblik den nedbrydes $«{ }^{69}$ som endnu et bidrag til mængden af de forklarelsens skinmetaforer, som vi tit møder hos Benjamin: »...begrundet i selve formen for hendes $s k i n \ll, » e t$ helt andet skin er det end det triumferende $s k i n \ll, »$ forsoningens skin«, »lig en stjerne der falder fra himlen«, »før-skin« etc.

Hvis man skulle oversatte begrebsparret »Sachgehalt« og »Wahrheitsgehalt« måtte det være vigtigt at bibeholde deres indbyrdes relative afhængigheds- og modsætningsforhold. Semiotikken leverer som bekendt flere modeller, der tilgodeser det, men denotations-konnotationsmodellen, sådan som Barthes anvender den i den reversible udgave, modsvarer disse krav. Sådan at forstå at sachgehalt både kan læses i denotativt og i konnotativt perspektiv. Konnotativt i forhold til det fornuftens denotationssystem, som myten i Valgslagtskaberne er indhold for, og denotativt i forhold til wahrheitsgehalten (urbillederne) som konnotation. Lad mig visualisere det vel vidende, at jeg foretager en oversættelse af Benjamin:

Grundmodellen er den velkendte tegnmodel udbygget med konnotationen og reversibiliteten mellem denotationen og konnotationen: 


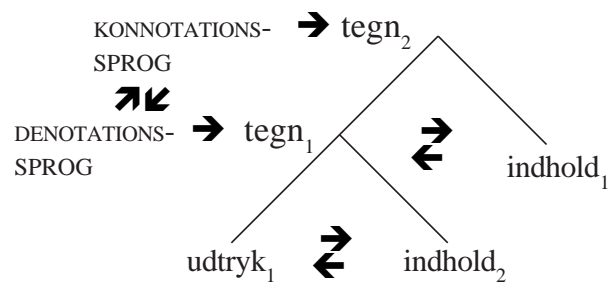

Modellen for Benjamins læsning af Goethes Valgslagtskaberne, hvor hvert 'højere' niveau er konnotation for hvert 'lavere' som denotation:

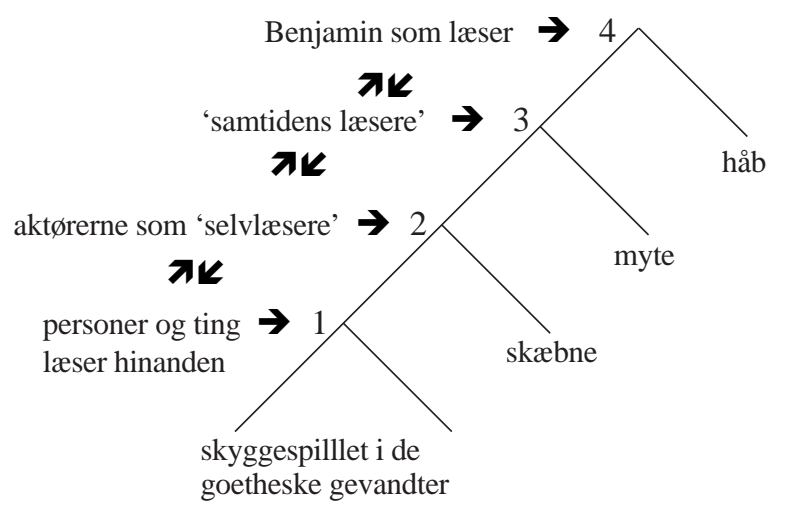

1. niveau er selve skyggespillet i de goetheske gevandter, som det umiddelbart udspiller sig blandt mennesker og ting. Det fungerer som denotation for 2. niveau, som er personerne fremstillet i og med deres liv som underlagt og kæmpende mod, hvad man opfatter som skæbnens magt. I forhold til 1. niveau konnoterer fremstillingen skabne. Den fungerer samtidig som denotation for 3. niveau, som er samtidslæserens fremstilling af (og forfatteren Goethes egen mening om) aktørernes forholden sig til skæbnen: naturen sejrer til sidst over fornuften. I forhold til 2. niveau konnoterer fremstillingen myte. Den fungerer samtidig som denotation for 4. niveau, der er læseren Benjamins fremstilling af, hvad der foregår i og med tekstualiteten, dvs. den faktiske tekst og investerede skribent- og læserroller, incl. hans egen. Her befinder f.eks. Goldbæks fortalleren Goethe ${ }^{70}$ sig. Den Goethe Benjamin 'redder'.

Benjamin læser (a) tre mytiske bestræbelser i teksten og (b) to brud med myten: (a) Naturen betragtet som myte, Rationaliteten betragtet som myte og Urbillederne som mytisk formidling af en ekstratekstlig meningsfuldhed. (b) 
naturmyten brydes i kampen for rationaliteten og rationalitetsmyten udfordres $i$ antitetiske allegorier. Viljen til forsoning midt i håbløsheden fungerer som billede på håbet. Heri ligger romanens selvforståelse, som samtidig må være dens meddelbarhed eller oversættelighed. Dens 'skrivelighed' kunne Barthes finde på at kalde den, ${ }^{71}$ fordi det er det ved romanen, der kun kan fremstilles som genskriven, ikke repræsenteres i f.eks. en tolkning. Det ville jo være at vende tilbage til den rationalitetsmyte, som netop er under anklage.

Benjamin kalder den analyse, der befinder sig på niveau $1-3$ for Kommentaren. Den beskæftiger sig med værkets Sachgehalt. Og den analyse, der går videre, niveau 1-4, og indstiller sig mod værkets Wahrheitgehalt, kalder han for Kritikken. Dette svarer med lidt god vilje til en skelnen mellem henholdsvis den strukturelle og den tekstuelle analyse. ${ }^{72}$

Vores læsning (og Benjamins) af myten har sin pendant i skribentrollen. Skribenten påtager sig her to hovedroller. Den ene investeres i den særlige fremstilling af dagliglivets skæbnekarakter, som leverer føden til mytens liv. Myten lever af det særlige ved den måde, livet former sig på. Den anden (»fortalleren Goethe «) investeres i en nedbrydning af myten gennem forskellige karikeringer af aktørernes skæbnetro. Det er altid måden hvorpå, det er altid som form, at en denotation bliver udtryk for et nyt indhold. En struktur som Barthes så stimulerende har redegjort for i »Myten i dag « og som i øvrigt ligger bag hans allegoriske blik på megen af den litteratur, han læser og 'redder' på samme måde, som Benjamin 'redder' barokken og Goethe. Men det er vigtigt at bemærke sig, hvis man sammenligner de to modeller, at i den semiotiske læse-skrivemodel eller med lidt mere Benjamin-nære termer, erkendelsebenævne-model findes syntesemuligheden ikke som en transcendent helhedsstørrelse, men - når det sker - som en dennesidig erkendelse og ny benævnelse, som for Barthes har kropslig karakter og kan have kvaliteten nydelse (jouissance). Mao. utopien virkeliggjort, men som teater. Gladen (plaisir) er af mindre frydefuld karakter og stort set knyttet til genkendelsen og legitimeringen.

Benjamin og Barthes er enige om, at et værks sandhed ikke ved analyse kan trækkes frem og betragtes, den kan kun gribes i farten, fremstilles, »fanges i en diskurs «, som Barthes siger om størrelsen »Tekst« [tekstualitet], men det kan den så også. Når det lykkes, er det sket, tættere kommer du ikke på. Du behøver ikke at vente på, at der skal komme én og sanktionere, hvad du har udrettet. Du kommer ikke tættere på, i det regi! For Benjamin kan sandheden end ikke fanges i en diskurs, kun billedet på den, og vel at mærke ikke som afbillede, men som modbillede. Til gengæld tillader han sig at have sandheden som fjernt utopisk sigtepunkt: »Mysteriet er det moment i det dramatiske, hvor dette bevæger sig fra sit eget sprog og ind i et højere sprog, der er 
uopnåeligt for det første sprog. Det (mysteriet) kan derfor aldrig komme til udtryk i ord, men ene og alene i fremstillingen, det er det 'dramatiske' i strengeste forstand $\ll{ }^{73}$ Dette er essensen i Benjamins Darstellungs-begreb (fremstillen) over for Barthes' écriture-begreb (skriven). Begreberne benævnelse, talen og udfolden hører til i samme kategori.

Varkets autonomi. Det er med baggrund i samme angst for en systemtænkningens magtfulde og eventuelle terroristiske konsensus om, hvad der er sandt, og hvad der er godt i erkendelsen og i tilværelsen som sådan, at Benjamin argumenterer for værket som sandhedsgestalten par excellence, og at Barthes afviser ved litteratur at forstå »et korpus eller en række værker«. I samme ånd ville Roman Jakobson ikke reducere den poetiske sfære til poesi og omvendt ikke begrænse poesi til den poetiske funktion. ${ }^{74}$ Værket er for Barthes en stærkt kodet, strukturel helhed som »udskilles imaginært af Teksten [tekstualiteten $] \ll{ }^{75}$ Men Benjamin absoluterer alligevel ikke værket, tværtimod. Når Benjamin insisterer på værkets autonomi, er det dels for at modvirke en tendens til centralisering og sektorisering af videnskaben og erkendelsesformerne, dels for at støtte det litterære værks status som uanekterbart - i kraft af sin særlige eksemplariske form for sandhedsgestaltning - af en hermeneutik, der vil betragte værket som metaforisk i forhold til en sandhed. Tanken om det absolutte veg Benjamin ikke fra, men den kunne kun nås ad metonymisk billedlig vej. Om vejen var Barthes og Benjamin ikke uenige. Men også for Barthes er der for meget magtsprog og -tænkning og institutionalisering knyttet til værket og værkhistorien til, at det kunne bruges som absolut model. Så måske Benjamin ville have bifaldet Barthes’ udødelige definition på litteratur:

»Dette velgørende snyderi, dette dribleri, dette herlige bluff, der gør det muligt at opfatte sproget uden for magten, i glansen af en sprogbrugens permanente revolution, kalder jeg: litteratur. ... ved litteratur forstår jeg ikke et korpus eller en række værker, heller ikke engang en handelsbranche eller en undervisningssektor, men den komplekse graf af praksisspor: sporene af en skrivepraksis. «76

Det er altså den litteratur, Barthes vil 'redde', ikke for eftertiden som et klenodie, men for erkendelsen af den i benævnelsen. Jeg kan eksempelvis minde om hans kendte analyse af Balzacs novelle $»$ Sarrasine $\ll^{77}$ og om hans læsning af Flaubert, ${ }^{78}$ selv om Flaubert hører til de forfattere, der i et lineært tidsligt perspektiv er begyndt at 'redde' sig selv ved, som Barthes siger ved flere lejligheder, at gå fremad, mens han peger på sin maske, eller om læsningen af dramatikeren Baudelaire, hvor Barthes i en meget spændende analyse ${ }^{79}$ læser det 
håbefulde i Baudelaires fiasko som dramatiker som baggrund for Les Fleur du mals særlige form.

I artiklen »Tacite et le baroque funèbre« (Tacitus og dødens barok) ${ }^{80}$ leverer Barthes en analyse af Tacitus' Annaler (ca. 90 -100 e.k.), hvad angår de romerske rædselsregimers (Tiberius) spreden d $\varnothing \mathrm{d}$ og $\varnothing$ delæggelse. Formålet er at analysere det barokkes fremstilling af $D \phi d e n$. Analysen er interessant i denne sammenhæng, fordi den udover at være kongenial - hvad angår det barokke med Benjamins baroksyn som det fremtræder i Sørgespilsanalysen, dels bekræfter hans reddende og aktualiserende betragtningsmåde ud fra analyse af et ikke-litterært materiale af køøniketypen, dels giver et eksempel på slægtskabet mellem Barthes' diskursteori og Benjamins historiesyn. Barthes slutter sin læsning af Tacitus' fremstilling af den ene rædselsvækkende dødsmåde efter den anden på følgende vis: »At dø, her, er at fornemme livet. ... alt reproducerer sig, og dog gentager intet sig, det er måske betydningen af dette Tacitus' univers, hvor den strålende beskrivelse af $F u g l F \emptyset n i x^{81}$ synes at fastlægge d $\varnothing-$ den som livets reneste $\varnothing j e b l i k \ll .{ }^{82}$ Artiklen udkom 1959 i tidsskriftet $L$ 'Arc, i $\emptyset$ vrigt samme år som Benjamins Oeuvres Choisies udkom i Paris (hvor Sørgespilsbogen dog ikke var medtaget).

Symbol og semiotik. Set i perspektiver som disse virker det jo ikke så mærkeligt, at en semiotisk tilgang til Benjamin er givende. Det indirekte eller det symbolske er fra »Skabelsen « grundlaget i hans opfattelse af menneskenes måde at reflektere på. For Benjamin er ideen sprogets symbolske væsen eller det ved sprogets væsen, som er symbolsk. I første omgang ikke så langt fra Saussures forståelse af tegnet, som på den ene side er arbitrcert både i forhold til virkelighedsreferencen og internt $i$ relationen mellem le signifiant og le signifié, og på den anden side et rent 'åndeligt' fænomen eller bevidsthedsfænomen, som vi vist plejer at kalde det; le signifié er et 'concept' (begreb) og le signifiant er et 'image', et indre billede. Men for Benjamin er denne 'afstand' dog ikke konventionelt bestemt. »Sproget giver aldrig blotte tegn $\ll{ }^{83}$ Mennesket er godt nok skabende, men også receptivt skabende. Tingene er skabt af Guds ord og erkendes ved det navn, som mennesket giver tingen på invitation fra dem. Tingen meddeler sig, og denne meddelen sig kan mennesket opfatte, og i overensstemmelse hermed giver mennesket tingen navn. $I$ dette navn meddeler mennesket sit åndelige væsen til Gud, men det er en anden historie.

Det, der adskiller Benjamins sprog- og tegnopfattelse fra Saussures, er samtidig det, der orienterer ham mod Barthes'. Det skal forstås på den måde, at i det semiotiske opgør med Saussure, som det bl.a. blev formuleret af Barthes, Kristeva og Derrida, ${ }^{84}$ blev Saussures tegnopfattelse kritiseret for at være statisk, nominalistisk, logocentrisk og formalistisk i betydningen 'algebraisk', 
hvilket i øvrigt var Roman Jakobsons begrundelse for at afvise Louis Hjelmslevs fors $\emptyset$ g på at adskille fonem og lyd. En form-substans problematik, som kan have en beslægtethed med den om sprogets arbitraritet eller intentio, som vi er i gang med her. Form-substansproblematikken vil jeg dog lade ligge i denne omgang. ${ }^{85}$ I stedet blev der formuleret udkastet til en semiotik, der var mindre mentalistisk, mere substantiel, idet den forholdt sig til praksis på en mere indgående måde end Saussures tegns distributionelle liv i samfundet, og frem for alt var den overhovedet dynamisk og åben. Men det var den udstrakte forståelse for dialektikkens og reversibilitetens fundamentale betydning for sprog- og tegndannelse og brugen heraf, der lå bag forestillingen om, at den enkeltes diskurs kun eksisterede i kraft af en andens diskurs, og altid er rettet mod denne, samtidig med at den er rettet mod det, den taler om.

Kristeva formulerede det dengang tydeligt i begreberne om translingvistikken og intertekstualiteten ${ }^{86}$ og senere i hendes skelnen mellem det semiotiske og det symbolske, ${ }^{87}$ som to uadskillelige sider af betydningsdannelsen. En skelnen som samler erfaringer, som strækker sig langt tilbage i vores liv med sproget og tegnene. Det er den intentio, der ligger i rettetheden eller orienteringen, dette altid allerede, der danner broen til Benjamins meddelbarhedssemiotik, eller semio-symbiose. I artiklen »At læse sygdomstegn $\ll^{88}$ har jeg fors $\emptyset \mathrm{gt}$ at vise, hvorledes denne symbiose udfolder sig i kroppens, patientens og lægens eller behandlerens respektive symptomlæsning og narrative fremstilling. ${ }^{89}$ Barthes har i artiklen »Den tredie mening $«{ }^{90} \mathrm{i}$ en billedanalytisk sammenhæng behandlet den uhyre komplekse, mimetiske kommunikationsform, som i særlig grad kunsten og litteraturen betjener sig af, og som i sin skelnen mellem den åbenbare (obvie) og den akave eller stumpe mening (obtus) sætter fokus på overgangen fra det semiotiske til det symbolske eller mere specifikt fra det denotative til det konnotative..$^{91}$

På den måde kan sproget både stå for det, det siger (symbolet) og for det, det netop ikke siger (allegorien), og det kan det i kraft af, at det både er det, det siger (meddelbarhed) og ikke er det (meddelelse). Benjamin gør ved flere lejligheder opmærksom på denne forbindelse mellem sprogets »symbolske« måde at fungere på og tegnet, hvor han også giver udtryk for sin forståelse for kompleksiteten i tegnets funktionsmåde:

»Sproget er nemlig i alle tilfælde ikke blot meddelelse af det, der lader sig meddele, men også symbol på det, der ikke lader sig meddele. Denne symbolske side af sproget hænger sammen med dets forbindelse til tegnet, men strækker sig for eksempel også i visse henseender over navn og dom. Disse har ikke alene en meddelende side, men højst sandsynligt også, snævert forbundet med denne, en symbolsk funktion. « ${ }^{92}$ 
I antitesen krydses atter deres veje. Her forbindes f. eks. deres forestilling om, at det allegoriske modbillede skaber det spændingsfelt i teksten, der er i stand til at forløse alt det forkrampede og ufrie i tilværelsen. Forløsningen sker altså 'indefra', fra sprogets konkrete brug af de emblematiske stereotyper. ${ }^{93}$ Og ikke 'udefra' som en allerede eksisterende sandheds eller forløsnings nedslag i en symbolsk indirektehed i teksten. Hos Benjamin og barokken sker dette med rødder i antikkens hieroglyffer, ${ }^{94}$ hos Barthes med rødder i den daglige tales doxa, som f.eks. i hans læsning af kærlighedens fragmenterede tale ${ }^{95}$ og dagligdagens myter. ${ }^{96}$ I Benjamins kritik af den klassisk-romantiske æstetiks »profane symbolbegreb « og påpegningen af erkendelsespotentialet i det dialektiske allegoribegreb ligger der en med Barthes fundamentalt set samstemmende holdning til sprogets både indholdsmæssige og udtrykmæssige semiotiske måde at fungere på.

»Alt det mimetiske ved sproget kan snarere, ligesom flammen kun komme til syne ved hjælp af en bærer. Denne bærer er det semiotiske. Således er meningssammenhængen ved ordene eller sætningerne den bærer, hvorved ligheden først som et lyn kan komme til syne. For dens frembringelse gennem mennesket $\mathrm{er}$ - på samme måde som opfattelsen af den gennem mennesket - i mangt og især i de vigtige tilfælde bundet til en pludselig opblussen. Ligheden haster forbi. Så er det ikke usandsynligt, at hurtigheden i skrivningen og læsningen forøger sammensmeltningen af det semiotiske og det mimetiske inden for sprogets område. $\ll^{97}$

I den klassisk-romantiske forståelse skulle det symbolske, qua sin blotte frembringelse eller fremtoning, formidle en direkte overførsel af det Skønne til det Sande (det guddommelige). ${ }^{98}$ Det er, ifølge Benjamin, i sådanne mystificerende betragtninger om det symbolske, at den traditionelle kunstkritik finder grobund for sine forestillinger om den faste og statiske forbundethed mellem udtryk og indhold og følgelig - i mangel på dialektisk fornemmelse og erfaring - undgår at tage hensyn til indholdet i udtryksanalysen og udtrykket $\mathrm{i}$ indholdsanalysen. ${ }^{99}$

Det er som modsætning til den klassicistiske direkte inderlighed i forståelsen af, hvordan litteraturen fungerer og virker, at Benjamins fokusering på allegoriens dialektiske modsætningskarakter skal forstås. ${ }^{100}$ I sin karakter ikke så forskellig fra Lévi-Strauss' myteteorier, tænk på Ødipus-analysens koblinger af indbyrdes modsætningsstrukturer. Modmyten taler (i betydningen læser/ taler: forstår den $i$ sig, $i$ sit sprog) primærmyten i kraft af modsætningen, vel at mærke på fælles grundlag. Dialektikken fungerer kun på en fælles semantisk akse. Myten taler sit eget sprog, som også Barthes pointerede det i »Myten i 
dag «. »Myten er tale«. En anden tale end den umiddelbare. På samme måde udfordrer allegorien den etablerede tale, den tilbyder sig som modbillede, for kun i samspillet med det åbnes det forhærdede (det emfatiske) og illusoriske i den umiddelbare tale.

For Benjamin, og det skal ikke fortrænges, indeholder denne krakeleringsteori et håb om ad denne vej og kun denne konkrete vej at vende tilbage til helheden, en erkendelse af og et liv i sjælelig og kropslig enhed og balance. Men selv om denne paradoksalitetens metode par exellence for Benjamin har dette mål, så synes flere momenter i metoden at pege på, at han og Barthes snarere stiler mod et mere 'realistisk' mål, en sprogets epistemologi, en erkendelseslære, som er funderet i menneskets liv og erfaring i og med sproget. På en måde var det jo også udgangspunktet, faktisk for dem begge. Skabelsesberetningen for Benjamin og den tilsvarende forestillingen om et ubesmittethedens sprog, der må ligge bag det tidlige begreb hos Barthes om en écriture blanche,${ }^{101}$ som en skrivningens fata morgana. Forestillingen om écriture blanche hænger sammen med en faktisk pågående 'afsakralisering' og 'deritualisering' af måden at skrive litteratur på, som f.eks. Mallarmé o.a. praktiserer. Et opgør med de naturaliserende og mytologiserende tendenser i vurderingen af litterær sprogbrug. Målet var »at skabe en hvid écriture, der er befriet for enhver form for afhængighed af en bestemt sprogbrugens norm « ${ }^{102} \mathrm{Et}$ forsøg på at skabe en litterær form, der brød med det stereotype, med clicheerne, med manererne samtidig med, at den genetablerede sig som en »neutral«, »uskyl-

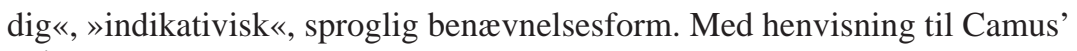
l'Étranger resumerer Barthes:

»écrituren reduceres altså til en slags negativ modus, hvor de sociale og mytiske karakteristika i en sprogbrug ophæves til fordel for formens neutrale og ubevægelige status; tanken bevarer således al sin ansvarlighed, uden at udfylde et accessorisk engagement over for formen i en historisk situation, som ikke passer til den. $\ll^{103}$

Målsætningens beslægtethed med Benjamins bliver mere og mere evident. Barokkens allegoriske mod-sprogstruktur, som altså fungerer ved hjælp af hieroglyfiske helligheder, skal ifølge Benjamin læses som (Barthes ville sige konnoterer) et udtryk for forestillingen om et adamistisk sprog. »Allegorien er begge dele, konvention og udtryk; og det er i bund og grund modstridende « ${ }^{104}$ Det barokke sørgespil er i sin form fragmentarisk artikuleret, som sproget er det. Det er delene, der taler helheden ikke som en addition, men snarere som en multiplikation. »Det er måske det, der er det barokke: en progressiv mod- 
sætning mellem enheden og helheden, en kunst hvor udstrækning ikke er summativ, men multiplikativ, i korthed en accelerativ tæthed «. ${ }^{105}$

Som myterne og folkeeventyrerne i øvrigt, der taler deres sorg. Et 'bricolage', som vi først mødte det hos Lévi-Strauss, men som vi indser er et fundamentalt vilkår for vores semiotiske måde at meddele os på. At læse disse spil er som at foretage et aktivt sorgarbejde. Man går den møjsommelige vej, som man skal gå for på gyldig vis at forstå, hvad der bliver sagt. Som det ene haiku-digt, der læser det andet. Som læser, læser man i sit eget sprog. Og det, man læser, er det andet sprog. I dette tilfælde det barokke sørgespil, som opfører et sprog, hvor koden er kendt. ${ }^{106}$ Den består af kulturelt fastlagte entydigheder, som i det særlige allegoriske skyggespil vækker læserens egen sprogformåen.

\section{Sandhed og skønhed}

Barthes måtte opgive håbet om den totalt ubesmittede skriven, der ikke skulle »stå til tjeneste for nogen triumferende ideologi ${ }^{107},{ }^{10}$ fordi »intet ['når alt kommer til alt' (m. tf.)] er mere utro end en hvid écriture $«,{ }^{108}$ og han reviderede siden écriturebegrebet fra at være en diakron, transitiv størrelse til at være en diakron, intransitiv størrelse. Tilsvarende synes Benjamin at være på kollisionskurs med sig selv. Hans helhedsutopi som en tilbagekomst til Guds ord forhindrer ham i at opnå den endelige forsoning af krop og sjæl i den menneskelige sproglige udfoldelse, som Barthes på sin side leverer udkast til en tekstualitetsteori om. Men da Benjamin insisterer på den eksemplariske, brudfyldte sandhedsgestaltning i litteraturen, som vi har set det, i et stadigt modernitetsperspektiv og ikke »klassiko-centristisk «, som Barthes kaldte det, så virker det desto vanskeligere at argumentere for en ekstratekstlig helhedssyntese. Og når Benjamin alligevel synes at måtte gøre det, gavner det snarere den nykantianistiske fremskridtsideologi om harmoni, fred og fordragelighed mellem menneskene end hans vigtige erkendelseskritiske projekt om videnskabens og litteraturens fremstilling og udfoldelse »ikke af det faktiske, men af det autentisk-mulige $\ll .{ }^{109}$

Den benjaminske forløsning befinder sig i allegoriens illusionsløse indsigtsfuldhed i myteunderlaget, grundet $\mathrm{i}$ et sanseligt nærvær, men kombineret med en forventning om omslaget i symbolet, som syntesen, den endelige sandhedseller gudsreference. Den barthesske forløsning befinder sig samme sted, hvad angår det allegoriske niveau. Og han kunne sådan set også godt forestille sig det imaginæres sprog, som en sprogets utopi, men da han betragter sproget som kroppens fortabelse og det at skrive sin læsning som selve den kropslige, 
forløsende handling, med nydelsen derved (når det lykkes) som en syntese, ${ }^{110}$ må han i bestræbelsen for at nå virkeligheden »opgive sin 'oprigtighed' «"11 og ikke se sig tilbage!:

»Nogen burde lære mig, at man ikke kan skrive uden at opgive sin 'oprigtighed' (stadigvæk Orfeus-myten: se dig ikke tilbage). Hvad skriften forlanger, og hvad ingen forelsket kan gå med til uden at sønderrives, er at ofre en smule af det Imaginære og på den måde sikre en smule virkelighed indpas gennem sproget. ... Det Imaginæres sprog ville vare [m. fr.] intet andet end sprogets utopi; et helt oprindeligt, paradisisk Adam-sprog, et 'naturligt sprog ... helt fri for forvrængning og illusion, ... en skyfri spejlen af sanserne ... det sanselige sprog (die sensualische Sprache)'. 'I det sanselige sprog taler alle sjæle med hinanden, de behøver intet andet sprog, for det er naturens sprog'.

Vide at man ikke skriver for den anden, vide at de ting, jeg vil skrive, aldrig får den, jeg elsker, til at elske mig, vide at skriften ikke kompenserer for noget, ikke sublimerer noget, at den er lige præcis dér hvor du ikke er - det er begyndelsen til skriften $\ll^{112}$

Derved adskiller Barthes sig umiddelbart fra Benjamin på et væsentligt punkt, som synes at hænge sammen med forskellen i deres opfattelse af og interesse for læseren. Det hænger igen sammen med den kendsgerning, at der hvor Benjamin ikke kunne søge syntesen i mødet eller konfrontationen med den anden i lacansk og psykoanalytisk forstand, som Barthes synes at gøre, selv om alt i Benjamins måde at forholde sig til litteraturens sprog på peger i den retning, der springer Benjamin så at sige i målet. Ikke fordi han påkalder sig den elskende som sandhedsvidne, det er både i overensstemmelse med Barthes og en immanens-betragtning, men fordi han som svar på det relevante spørgsmål, »om sandheden formår at yde skønheden retfærdighed «, henholder sig til Platon, der »tilskriver sandheden den opgave at lade skønheden stå inde for væren «. Sandheden er transcendent og er mere end skønheden for Benjamin. Mens Barthes jagter sandheden $i$ skønheden, og må erkende, at sandheden aldrig vil kunne yde skønheden retfærdighed. Skønheden er mere end sandheden.

»Eros er ikke utro over for sin oprindelige stræben, når han retter sin længsel efter sandheden; thi også sandheden er skøn. Den er ikke så meget skøn i sig selv, som for Eros. Det samme galder i den menneskelige karlighed: mennesket er skønt for den elskede ikke i sig selv; og netop fordi dets krop fremstiller sig i en hфjere orden end det skфnnes orden. 
Sådan er det også med sandheden: skøn er den ikke så meget i sig selv som for den, som søger den... Sandhedens vaesen, som det sig selv fremstillede idérige, inkarnerer snarere, at talen om sandhedens skønhed aldrig kan blive afbrudt. ... Det skønnes fremtræden som forfører, så længe det ikke vil andet end at fremtræde, trækker forstandens forfølgelse efter, og lader kun sin uskyld erkende dér, hvor det flygter til sandhedens alter. Eros følger denne flugt, ikke som forfølger, men som elskende; på en sådan måde at skønheden for sin egen fremtrædens skyld altid undflyr begge af frygt for det forstandige og af angst for den elskende. Og kun den elskende kan bevidne, at sandheden ikke er afsløring, der tilintetgør hemmeligheden, men i stedet åbenbaring, der yder den retfærdighed. Om sandheden formår at yde skønheden retfardighed? dette er det inderste spørgsmål i Platons Symposion. Platon besvarer det, idet han tilskriver sandheden den opgave at lade skønheden stå inde for varen. I denne forstand udfolder han altså sandheden som det skønnes indhold. «113

»Mennesket er skønt for den elskede ikke $i$ sig selv«, og netop fordi dets krop $»$ fremstiller sig i en højere orden end sig selv«. Sandheden er skøn for »den, som søger den«. »Det skønnes fremtræden, som forfører ...«. »Kun den elskende kan bevidne «, at sandheden ikke træder frem gennem en afsløring, men »viser sig gennem en fremgangsmåde «. ${ }^{114}$

Så kom kroppen endelig i fokus, her betragtet i Benjamins særlige prisme, men Barthes ville nyde problemstillingen, for som han siger: »Jeg drømmer ikke, jeg danner sætninger: det er kroppen som jeg betragter den, og ikke længere kroppen, som jeg lytter til den, der får en fatisk (kontaktmæssig) funktion ved, mellem min sprogproduktion og det flydende begær, som denne produktion næres af, at knytte an til en iagttagen, ikke et budskab «. ${ }^{115}$

Som vi så det hos Benjamin, er mennesket benævnende og erkendende i sproget, men det blev skabt af materien. Mennesket blev skabt i Guds billede, dvs. i billedet af den skabende substans, som er sproget. Altså også kroppen er skabt i billedet af skabersproget. Dvs. kroppen, ens egen og andres, er erkendbar i benævnelsen, men vel at mærke den del eller det aspekt af den, der lader sig meddele. Samtidig er benævnelsens karakter afhængig af, hvorledes den lader sig meddele. For som vi husker »det åndelige væsen er kun identisk med det sproglige, for så vidt som det lader sig meddele $\ll .{ }^{116}$ Med andre ord det, vi taler om, er kroppens sproglige kommunikerbarhed. Kroppe kommunikerer som bekendt også udmærket uden ord. De har som alle andre ting i naturen deres eget stumme sprog. Det er dette stumme sprog, vi med vores verbalsprog oversætter og tilføjer erkendelse. 
Vi kan altså slutte, at heller ikke sandheden om kroppen er skøn i sig selv, men det kan den blive i en (litterær) fremstilling, en selv-fremstilling og kun for den, som er indrettet mod den. For Barthes (og for Benjamin) har Sandheden ingen relation til det intentionelle: sproget meddeler det, der lader sig meddele, og det, der lader sig meddele er det sproglige. Sandheden indlader sig ikke med hensigten, den viser sig som en fremgangsmåde. For Barthes er Sandheden fremstillingens tilnærmelseskarakter, f.eks. det at skrive (eller på anden måde udfolde) sin læsen. Det er den eneste mulige kombinatorik mellem erkendeverdenen og leveverdenen.

\section{Noter}

1. Roland Barthes: »Littérature et méta-langage« in Éssais critiques, Paris 1971 (orig. 1959), p. 107.

2. Roland Barthes: Litteraturens nulpunkt, Kbh. 1968, p. 68 (m. fr.). Oversættelse af Le Degré zéro de l'écriture, Paris, 1953. Se også samme p. 20 og Karlighedens forrykte tale, Kbh. 1987, p. 197, oversættelse af Fragments d'un discours amoureux, Paris 1977.

3. Walter Benjamin: Der Begriff der Kunstkritik in der deutschen Romantik (1919) in Gesammelte Schriften, I, 1, Frankfurt am Main 1974, som citerer Johann Gottlieb Fichte: Sämtliche Werke, bind I, (1845-1846), Berlin 1965, p. 67: »[Die] Handlung der Freiheit, durch welche die Form zur Form der Form als ihres Gehaltes wird und in sich selbst zurückkehrt, heißt Reflexion«.

4. Johann Gottlieb Fichte: Das System der Sittenlehre nach den Principien der Wissenschaftslehre in Sämtliche Werke, bind IV, (1845-1846), Berlin 1965, pp. 23-24.

5. Walter Benjamin: »Om sprog overhovedet og om menneskets sprog « in Tore Eriksen (red.): Walter Benjamin - oversat, Århus 1989, p. 1. Oversættelse af »Über Sprache überhaupt und über die Sprache des Menschen« in Gesammelte Schriften, II, 1, Frankfurt am Main 1977.

6. Jf. Samuel Beckett: Murphy, London 1963 (org. 1938), hvor M.'s dagligliv er inddelt i rum eller zoner, der svarer til sprogets forskellige funktioner eller roller, som de er omtalt her. Hos M. er det Dantes tre stadier Inferno, Purgatorio og Paradiso, som er sammenligningen. I 1. zone har »formerne paralleller« siger M. »here the pleasure was reprisal, the pleasure of reversing the physical experience $($ p. 78), »her kunne hele den fysiske fiasko blive til en brølende succes«. 2. zone er kontemplationens og æstetikkens sfære. Her står den stol, som M. sætter sig i, når han vil bort fra registreringen af realiternes verden. Denne zone er fredens og individualitetens rum. 3. zone, Paradiso hos Dante, er målet for M.'s drømme. Det er det irrationelles sted, opløsningen i en større helhed, som han siger, den absolutte frihed. Jf. min analyse af bogen i John Thobo-Carlsen: Astetik og kommunikation, Odense 1984.

7. Roland Barthes: Lektion, in Roland Barthes: Om litteraturen. To lektioner, Kbh. 1985, p. 14-15. Oversættelse af Leçon. Leçon inaugurale de la chaire de sémiologie littéraire du Collège de France, prononcé le 7 janvier 1977, Paris 1978.

8. Walter Benjamin: »Fors $\varnothing \mathrm{g}$ på en kritik af volden« in Kulturindustri. Udvalgte 
Skrifter, Kbh. 1973, p. 28.

9. Roland Barthes: Af mig selv, Kbh. 1988, p. 158. Oversættelse af Roland Barthes, Paris 1975

10. Op.cit., p. 156.

11. En morsom udgave af dette sammenfald af kropslig sanselighed og tale er hans refleksioner over munden som både tale- og kysseorgan: »Lad os til denne dobbelte, sammesteds lokaliserede funktion, forestille os en fælles overskridelse, som er affødt af en samtidig brug af talen og kysset: tale under kysset, kysse under talen. Man må formode, at denne nydelse findes, eftersom de elskende ustandselig »drikker ordene af den elskedes læber«. Det, de smager, er da, i den forelskede kappestrid, meningens spil, som den folder sig ud og afbrydes: funktionen, som forstyrres: kort sagt: den stammende krop«, Barthes op.cit., p. 153.

12. Roman Jakobson: »Linguistics and Poetics « (org. 1960), in T. Sebeok (ed.) Style in language, Cambridge, Mass. 1966. Roman Jakobson anvender betegnelsen »the set toward ...« og skriver Einstellung i en forklarende parentes om det at indrette sig mod sig selv. Nu kan man altid diskutere, om sproget kan noget som helst af sig selv, eller om det ikke netop er i mødet mellem sprogbrugerne i henholdsvis læserog skribentrollen, at sproget udfoldes og altså også kan indrette sig eller indstille sig mod sig selv i den særlige form for kommunikation, der sætter dets egen meddelbarhed i fokus. For yderligere diskussion og anvendelse af dette sted hos Roman Jakobson henvises til Thobo-Carlsen: Estetik og kommunikation, p. 77ff. (se note 6).

13. En grundigere præsentation heraf gives i John Thobo-Carlsen: Ankomsten til virkeligheden. Om forholdet mellem litterar sprogbrug og lasning i forlangelse af Roland Barthes, Roman Jakobson og Walter Benjamin. Odense: Pjecer fra Institut for Litteraturvidensab og Semiotik, Odense Universitet 1993, hvis sidste afsnit nærværende artikel er en omarbejdet udgave af.

14. Benjamin: »Om sprog overhovedet...«, p. 48.

15. Johs. I,1.

16. Loc.cit., p. 44.

17. Loc.cit., p. 45.

18. Loc.cit., p. 46.

19. Loc.cit., p. 46.

20. Loc.cit., p. 47.

21. Loc.cit., p. 38-9.

22. Jf. Roland Barthes: Système de la mode, Paris 1967.

23. Loc.cit., p. 38

24. Loc.cit., p. 40.

25. Loc.cit., p. 43.

26. For mulig applikation af disse tanker jf. John Thobo-Carlsen: »At læse sygdomstegn «, in Agrippa. Psykiatrisk Tidsskrift, Kbh. 1993.

27. Walter Benjamin: Ursprung des deutschen Trauerspiels (org. 1925) in Gesammelte Schriften, I,1, Frankfurt am Main, 1974, p. 390.

28. Rodolphe Gasché: »Den saturniske vision og spørgsmålet om forskel: refleksioner over Walter Benjamins sprogteori« (orig. 1986), in Eriksen (red.): Walter Benjamin - oversat, pp. 183-208, p. 192.

29. Ferdinand de Saussure: Cours de linguistique générale, Paris 1968 (org. 1915), p. 101.

30. Roland Barthes: »Présentation«, in Communications 4, Paris 1964, p. 2: »Il faut en 
somme admettre dès maintenant la possibilité de renverser un jour la proposition de Saussure: la linguistique n'est pas une partie, même privilégiée, de la science générale des signes, c'est la sémiologie qui est une partie de la linguistique: très précisément cette partie qui prendrait en charge les grandes unités signifiantes du discours; de la sorte apparaîtrait l'unité des recherches qui se mènent actuellement en anthropologie, en sociologie, en psychoanalyse et en stylistique autour du concept de signification.«

31. Jf. Thobo-Carlsen: »At læse sygdomstegn« (se note 26).

32. Barthes: Lektion, p. 26.

33. Barthes: Af mig selv, p. 151, m. fr.

34. Roman Jakobson: Essais de linguistique générale, vol 1 og 2, (orig. 1963), Paris 1973, p. 28.

35. Jf. Kurt Gödel: »Über formal unentschiedbare Sätze der Principia Mathematica und wervandter Systeme I « in Monatshefte für Mathematik und Physik, vol. 38, 1931, pp. 173-198, og John Thobo-Carlsen: »Sémiotique de la lecture« in Degrés no. 72: L'interpretation (II), Bruxelles 1992.

36. Henning Goldbæk: De tavses sireners sang. Oplysningens dialektik hos den tidlige Walter Benjamin, Kbh. 1990, p. 125.

37. Intentio forstået iflg. Walter Benjamin: »Intention auf die Sprache als solche« $(G e-$ sammelte Schriften IV, 16) i et ikke-subjektivt og ikke-empirisk perspektiv, intentio ikke forstået som det, at bevidstheden igennem sin vilje har en hensigtmæssig relation til en Sandhed, som den vil have frem, men som det, at en diskurs er indrettet eller orienteret imod et eller andet, dens meddelbarhed. »Erkendelsesgenstand som én, der er bestemt gennem begrebsintention, er ikke sandhedens genstand «, Walter Benjamin : »Erkendelseskritisk fortale «, fortale til Ursprung des deutschen Trauerspiels in Eriksen (red.): Walter Benjamin - oversat, p. 96.

38. Roland Barthes: »L'aventure sémiologique« (org. 1974) in L'aventure sémiologique, Paris 1985, p. 13-14 (m. fr.).

39. Jf. John Thobo-Carlsen : »Læsningens semiotik«, in $K \& K$ 75, Kbh. 1993 og »Om glæden ved at læse« in Svejgaard og Thobo-Carlsen (red.): Fantasi og fiktion, Odense 1989.

40. Barthes: Lektion, p. 32-33.

41. Barthes måtte jo tage imod sin del, dels i forbindelse med argumentationen for afvisningen af disputatsen og ikke mindst i forbindelse med den langstrakte disput med professor Raymond Picard og en lang række universitære og andre personligheder af etableret og traditionel litteraturhistorisk og -tolkningsmæssig observans om Racine og litteraturvidenskaben. Barthes' bog Sur Racine udkom i 1963, men er skrevet i årene 1958-1960. Picards angreb på Barthes og den såkaldte Nouvelle Critique, som han mente Barthes tilhørte, Nouvelle Critique ou nouvelle imposture, kom i 1963, og Barthes' replik og opsamling, som samtidig var en skitsering af mulighederne for etableringen af en egentlig litteraturvidenskab, Critique et Vérité, kom i 1966. Samme år i øvrigt som Greimas' Semantique Structurale, der af mange bliver betragtet som grundlaget for og starten på litteraturvidenskab som selvstændigt universtetsfag, i hvert fald i Danmark. Det er interessant at konstatere. Men man må på den anden side nok sige, at Barthes i opgøret med Picard slog et af de slag, der tilsyneladende skulle slås på den kommende litteraturvidenskabs vegne. Interessant er det også, at det jo ikke kun var Barthes, der fik afvist disputatser eller disputatsudkast. Derrida fik i nogenlunde samme periode om beslægtede problemstillinger afvist en disputats i Paris, og Benjamin et habilitationsskrift i den 
ande ende af den europæiske akse Paris - Berlin. På trods af tidsforskellen vil jeg vove den påstand, at essensen i begrundelserne var nogenlunde ens. Barthes' anerkendelse kommer som et kompromis med professoratet ved Collège de France (ikke på initiativ fra Foucault, som antydet flere steder, men på initiativ af Barthes selv, og så senere understøttet af Foucault). Benjamins anerkendelse som universitetslærer kommer slet ikke, men han opnår dog en vis anerkendelse gennem Frankfurterskolen (f.eks. underviser Adorno et semester i 1931 i Benjamins kasserede habilitationsskrift (Benjamin: Ursprung des deutschen Trauerspiels, se note 27) ved Frankfurts Universitet). Derridas disputats bliver et Doctorat d'Etat sur travaux altså pr. kompilering af tidligere offentliggjorte arbejder, sådan klarede man den, som de facto.

42. Walter Benjamin: »Historiefilosofiske teser« in Kulturindustri. Udvalgte Skrifter, Kbh. 1973, p. 183 m. fr.

43. Barthes: Lektion, p. 22.

44. Paradoksien er også hos Benjamin en central æstetisk fremstillingsform: f.eks. Ursprung des deutschen Trauerspiels , p. 390 og »Erkendelseskritisk fortale«, p. 93. Hos Barthes utallige steder, men i Af mig selv, p. 78-79 diskuteres tillige paradoxas risiko for at slå over i doxa: også modsproget kan stivne.

45. Af mig selv, p. 150

46. Jf. »...om også sprogreceptivitet«, Benjamin »Om sprog overhovedet...«, p. 46.

47. En fin behandling af disse analyser findes i Goldbæk.

48. Koder må her forstås som en sproglig tendens, konvention eller et citations-perspektiv, der hos Roland Barthes i S/Z, Paris 1976 (org. 1970) og i »Tekstanalyse af en fortælling af E.A. Poe« in Tid Skrift for moderne litteraturvidenskab, nr. 3 (oversættelse af »Analyse textuelle d'un conte d'Edgar Poe« (org. 1973) in L'aventure sémiologique, Paris 1985) omtales som det déjà-vu, -écrit, -lu, -fait og vécu, dvs. som det 'allerede', der konstituerer vores kultur og alt, hvad vi foretager os. Jf. Thobo-Carlsen: »Læsningens semiotik « (se note 39), som behandler kodebegrebet bl.a. ud fra de nævnte tekster.

49. Harald Steinhagen: »Om Walter Benjamins allegori-begreb« (orig. 1978), Kultur \& Klasse 47, Kbh. 1983, p. 100-101. Jf. om inddragelse af referencepunkterne i studieobjektet, Roland Barthes: »Fra Værk til Tekst « in Kultur og Klasse 40, Kbh. 1981, p. 36-43; oversættelse af »De l'œuvre au Texte« (1971) in Le bruissement de la langue. Éssais critique IV, Paris 1984.

50. Jf. Benjamin: »Erkendelseskritisk fortale«, pp. 105-107.

51. Goldbæk, p. 98.

52. Benjamin: »Om sprog overhovedet...«, p. 96.

53. Af mig selv, p. 151.

54. Op.cit., p. 151.

55. Benjamin: Ursprung des deutschen Trauerspiels, p. 226.

56. Barthes: »L'aventure sémiologique«, p. 13.

57. »Oversætterens opgave« in Eriksen (red.): Walter Benjamin - oversat.

58. I artiklen »Roland Barthes: the critical subject (an idea for resarch)« in Paragraph vol. 11, no. 1, 1988, pp. 175-180 udkaster Peter Collier ideen om et studie af forholdet mellem Barthes og Benjamin: »A full-scale study of the conjunction of Barthes and Benjamin would be a daunting and exciting project « (p. 178). Jf. også Catherine Coquio, : »Roland Barthes et Walter Benjamin: image, tautologie, dialectique « in Catherine Coquio et Régis Salado (eds.): Barthes après Barthes. Une actualité en questions, Pau 1993 og Dieter Mettler: »Friedrich Schlegel - Walter 
Benjamin - Roland Barthes. Philosophische Begründungsversuche der Literaturkritik « in Wirkendes Wort. Deutsche Sprache und Literatur in Forschung und Lehre. Vol. 40 (3), 1990, pp. 422-434.

59. Roland Barthes: Mytologier, Gyldendal, Kbh. 1996. Oversættelse af Mythologies, Paris, 1957.

60. Jf. artiklerne »Sur la lecture « og »Écrire la lecture« i Le bruissement de la langue, som tages under behandling i Thobo-Carlsen: »Om glæden ved at læse« (se note 39).

61. Roland Barthes: Litteraturens nulpunkt (se note 2) leverer i kort form den litterære sprogbrugs historie.

62. Jf. bl.a. Thobo-Carlsen: »Om glæden ved at læse«.

63. Af mig selv, p. 151.

64. Den følgende læsning af Benjamins analyse af Goethes roman støtter sig til Goldbæk.

65. Walter Benjamin: Gesammelte Schriften I,3: 835-837: »Erster Teil: Das Mythische als Thesis (...) Zweiter teil: Die Erlöschung als Antithesis (...) Dritter Teil: Die Hoffnung als Synthesis«.

66. Goldbæk, p. 67

67. Walter Benjamin: Goethes Wahlverwandtschaften, (orig. 1925) in Gesammelte Schriften, I,1, Frankfurt am Main 1974, p. 140-141

68. Op.cit., p. 201.

69. Barthes: Litteraturens nulpunkt, p. 39.

70. Goldbæk, p. 80

71. $S / Z$, p. 11 .

72. Jf. henvisninger i note 39 .

73. Benjamin op.cit., p. 200-201; indtil sidste komma Goldbæks oversættelse, derefter min egen.

74. Jf. »Linguistics and Poetics«, p. 356.

75. Loc.cit., p. 37.

76. Barthes: Lektion, p. 14-15.

77. S/Z (se note 47 ).

78. Litteraturens nulpunkt (se note 2) afsnittet »Stilens håndværk«.

79. Litteraturens nulpunkt afsnittet »Baudelaires dramatik«.

80. Roland Barthes: »Tacite et le baroque funèbre« (orig. 1959) in Éssais critiques, Paris 1971.

81. VI, 34.

82. P. $111, \mathrm{~m}$. fr.

83. »Om sprog overhovedet...«, p. 46.

84. Jf. Thobo-Carlsen: Estetik og kommunikation, afsnittet »En skematisering af det semiotiske sted «, p. $241 \mathrm{ff}$.

85. Jeg har behandlet den i: Astetik og kommunikation, p. 61f. og p. 132.

86. Introduktion og henvisninger hertil se f.eks. Thobo-Carlsen: Asstetik og kommunikation, spec. afsnittet $\gg$ Tekstproduktion og det poetiske sprog «.

87. Jf. Julia Kristeva: La révolution du langage poétique, Paris 1974. Her foreslår hun i $\emptyset$ vrigt termen intertekstualitet erstattet med termen transposition (p. 60), fordi, som hun siger, der har været en tendens til at forstå intertekstualitet som en form for kildekritik. Med transposition vil hun pointere, at det at gå fra et betydende system til et andet kræver en hel ny formulering, dvs. såvel denotations- som udsigelsesmæssigt. 
88. Se note 26

89. Se også John Thobo-Carlsen: »At læse spillet« i dagbladet Information, d.18.6.92.

90. Roland Barthes: »Den tredie mening « in Kultur \& Klasse 44, pp. 20-39. Oversættelse af »Le troisième sens« (orig. 1970) in L'obvie et l'obtus. Éssais.

91. For en behandling af dette sat i forbindelse med Roman Jakobsons begreb om det poetiske, se John Thobo-Carlsen: »At læse det man ser« in Bo Hakon Jørgensen, Lars Ole Sauerberg, Anne Scott Sørensen (red.): At se teksten, Odense 1993.

92. Goethes Wahlverwandtschaften, $p$. 52. Derfor forekommer det mig ikke alene mere perspektivrigt, men også gyldigere at fremhæve lighederne mellem Benjamins sprog-, tegn- og semiotikopfattelse og Barthes' og Kristevas end modsætningerne, som f.eks. Lars Erslev Andersen gør det i »Benjamin on the Move. Om brugen af Benjamin i Amerika«, in Tore Eriksen et al. (red.): Tankestreger. Essays om Walter Benjamin, Århus 1989, p. 113 note 3: »Hos Benjamin henviser vendingen 'det semiotiske sprog' til et sprog, der er meningsbærende, intentionalt. 'Det semiotiske' har således den modsatte betydning hos ham end den betydning, som Julia Kristeva tillægger vendingen i Die revolution der poetischen Sprache (Frankfurt am Main 1978)«. For det første er intentionalitet hos Benjamin i denne sammenhæng sprogets indbyggede meddelbarhed og ikke et spørgsmål om, at et jeg manifesterer en eller anden hensigt, jf. ovf. For det andet er Benjamin fuldstændig bevidst om sprogets forskellige fremstillingslag, som det så smukt kommer frem i nedenstående Benjamin-citater fra »Om sprog overhovedet...«, p. 52 og fra »Om den mimetiske evne«, p. 123. På den anden side er det semiotiske hos Kristeva heller ikke det ukodede eller indretningsløse eller på anden måde blotte tilstedeværelse af mere eller mindre tilfældige partikulariteter som grundlag for tegndannelse (jf. beskrivelsen af symptomet i min ovn. artikel om sygdomstegn). Det semiotiske hos Kristeva består af et altid allerede artikuleret stade, som i sig selv ikke er tegn, men som er indrettet mod at skulle kunne indgå i en tegnrelation (»pré-signe«, Kristeva, p. 39). Tanken henledes på Hjelmslevs substans-kategori som formet mening. Tegnderivater eller -funktiver, som 'søger mage' til at indgå en tegnrelation med. F.eks. i diagnosticerings- og terapisituationen i form af at subjektet, der træder ind på scenen og påtager sig (ansvaret for) tegndannelsen ved at benævne fænomenet eller fortælle dets historie. Også Benjamins og Kristevas veje krydses i sproget, tegnet og benævnelsen som vejen til forståelsen.

93. Emblemata. Martin Opitz: Deutsche Poeterey (1624) kalder emblemerne for skjult teologi. Et emblem består af: billede (pictura), titel (inscriptio), epigram (subscriptio). (Goldbæk, p. 117 og p. 111: »de emblembøger som publikum var fortrolig med «). Benjamin nævner emblem bl.a. i Ursprung des deutschen Trauerspiels, p. 339. Se også Barthes’ fragment »Emblem/gag« in Af mig selv, p. 88.

94. Hieroglyffer. Benjamin citerer Schopenhauer (Ursprung des deutschen Trauerspiels, p. 338), der nævner hieroglyphe. »Allegoriens historiske baggrund var de enigmatiske hieroglyffer, som var et antikt rebussystem af billeder, der stod for ord og bogstaver. Dette antikke system blev opdaget i i renaissancen, hvor man troede, at de gådefulde hieroglyffer var de ægyptiske hieroglyffer, som man altså anså for at være guddommelige billeder«, Goldbæk, p. 117.

95. Jf. Barthes: Karlighedens forrykte tale.

96. Jf. Barthes: Mytologier.

97. Walter Benjamin: »Om den mimetiske evne« in Eriksen (red.): Walter Benjamin - oversat, p. 123

98. »Als symbolische Gebilde soll das Schöne bruchlos ins Göttliche übergehen«, 
Benjamin: Ursprung des deutschen Trauerspiels, p. 337.

99. »Bei diesem, dem vulgären Sprachgebrauch, ist das Auffallendste, daß der begriff, der in gleichsam imperativischer haltung auf eine unzertrennliche verbundenheit von Form und Inhalt sich bezieht, in den Dienst einer philosophischen Beschönigung der Unkraft tritt, der da mangels dialektischer Stählung in der Formanalyse der Inhalt, in der Inhaltsästhetik die Form entgeht«, Benjamin, op. cit., p. 336.

100. »Dem gegenüber ist die barocke Apotheose dialektisch. Sie vollzieht sich im Umschlagen von Extremen«, Benjamin, op.cit., p. 337.

101. I Litteraturens nulpunkt.

102. Litteraturens nulpunkt, p. 68.

103. Op.cit., p. 69.

104. »..die Allegorie ist beides, Konvention und Ausdruck; und beide sind von Haus aus widerstreitend «, Benjamin: Ursprung des deutschen Trauerspiels, p. 351.

105. Barthes: »Tacites«, p. 108.

106. Om læsning og koder se bl.a. Thobo-Carlsen: »Læsningens semiotik« (se note 39).

107. Litteraturens nulpunkt, p. 69.

108. Loc.cit., p. 70.

109. Goldbæk, p. 125.

110. En konstruktion som samler Barthes' bestræbelser lige fra det første møde med Viggo Brøndals neutralitetsbegreb (gennem Greimas) over le dégre zéro og écriture blanche, écriturens intransitivitet, til arbejdet med »le neutre«. Jf. også Bernard Comment: Vers le Neutre, Paris 1991.

111. Karlighedens forrykte tale, p. 197

112. Op.cit., p. 197. Barthes anfører, at de indskudte citater er af Jakob Böhme. Karrlighedens forrykte tale er skrevet på baggrund af en systematisk læsning af Goethes Die Leiden des jungen Werthers. Barthes nævner i denne bog også Jakob Böhme (s. 197), men da citeret efter Norman O. Brown Life Against Death. The psychoanalytic Meaning of History, London 1968 (1959) (da. 1973). Böhme levede 1575-1624. Han var tysk filosof, men ernærede sig som skomager. Han udviklede en teori om den indre sammenhæng mellem modsætninger: noget kan kun forklares ved dets modsætning. I forbindelse hermed teorier om det naturlige sprog og den sanselige sprog (die sensualische Sprache). Han var en af inspirationskilderne for mange tyske filosoffer, bl.a. Hegel, og også for Walter Benja$\min$.

113. Benjamin: »Erkendelseskritisk forsvarstale«, p. 91. m.fr.

114. Benjamin: »Erkendelseskritisk forsvarstale«, p. 92, m. fr.

115. Af mig selv, p. 154.

116. Benjamin: »Om sprog overhovedet ...«, p. 38 